\title{
KNJIŽNIČNA DJELATNOST U VARAŽDINU IZMEDU DVAJU SVJETSKIH RATOVA
}

$U$ ovome se radu autorica usredotočuje na međuratnu knjižničnu djelatnost te predstavlja društva i knjižnice čiji je knjižni inventar nakon završetka II. svjetskoga rata spojen s ciljem utemeljenja jedinstvene i javne knjižnične institucije u Varaždinu.

\section{UVOD}

Po završetku „Velikoga rata“ diljem novonastale države gradovi pokušavaju obnoviti sva područja ljudskoga djelovanja pa tako i društveni i kulturni život. Budući da je knjižnična djelatnost jedna od temeljnih kulturnih djelatnosti, u Varaždinu je revitalizacija kulturnoga života nakon završetka I. svjetskoga rata, između ostalog, obuhvatila i ponovnu uspostavu čitaonica i knjižnica u sklopu različitih društva, ali i osnutak javne gradske knjižnice. ${ }^{1}$ Jedinstvena i javna knjižnična ustanova imena Gradska knjižnica i čitaonica „Sloboda“ nastala je tek nekoliko godina nakon završetka II. svjetskoga rata ujedinjenjem knjižne građe međuratnih knjižnica Narodne čitaonice i Radničkog kulturno-umjetničkog društva „Sloboda“

1 Većinu podataka o međuratnoj knjižničnoj djelatnosti ekscerptirali smo iz šture primarne literature koju čine očuvani rukopisni zapisnici sa sjednica Narodne čitaonice, rukom ili pisaćim strojem pisani dopisi, popisi članova, memorandumi, blagajničke knjige, narudžbenice, računi, razni katalozi djela, a koji su dio arhivske građe Knjižnice i čitaonice „Metel Ožegović“ Varaždin. Među ostale krucijalne izvore podataka spadaju pisaćim strojem pisana pravila pojedinih društava, zatim varaždinske međuratne novine kao i spomenice Radničkog kulturno-umjetničkoga društva „Sloboda“ izašle prilikom obilježavanja značajnih godišnjica toga društva. 
te Gradske pučke knjižnice. ${ }^{2} U$ nastavku rada opisat će se svaka od navedenih knjižnica koje su djelovale u međuratnom razdoblju te predstaviti varaždinska društva koja su ih osnovala i unutar kojih su djelovale.

\section{NARODNA ČITAONICA}

Uoči završetka I. svjetskoga rata najznačajniji korak za nastavak čitaoničke i knjižnične djelatnosti u sklopu predratnog elitističkog i intelektualističkog društva imena Dvorana zbio se 1. studenoga 1918. godine kad se sastao prijevremeni odbor te nekadašnje vodeće kulturne institucije u Varaždinu, izmijenio pojedine dijelove društvenih „Pravila“ i donio odluku o nastavku rada u prostorijama gradskoga kazališta. Rukopisni zapisnik izvanredne skupštine Dvorane od 9. studenoga 1918. godine potvrđuje da su tadašnji članovi prihvatili izmjenu „Pravila“, donijeli

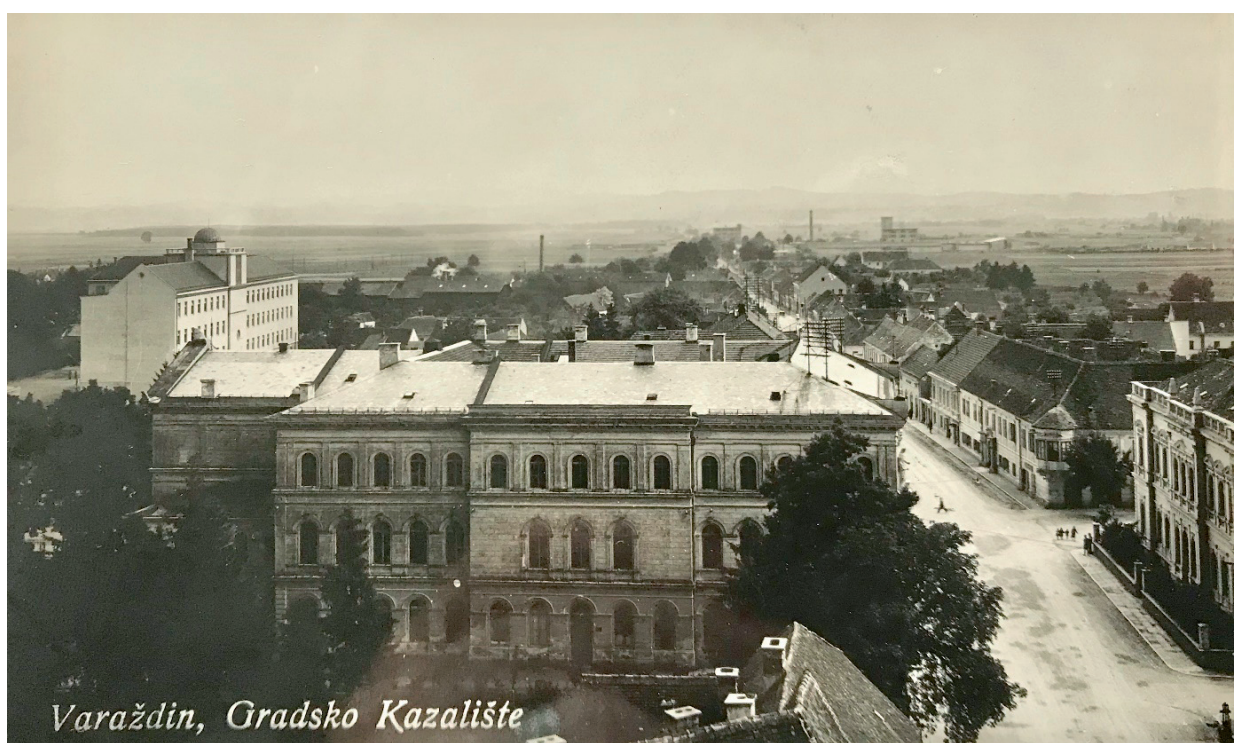

Slika 1. Varaždinska kazališna zgrada u prvoj polovici 20. stoljeća slikana sa sjeverne strane gdje je svoje prostorije imala Narodna čitaonica. ${ }^{3}$

2 Nakon prestanka rada inicijatora utemeljenja varaždinske Gradske pučke knjižnice, Jugoslavenskog akademskog društva „Tomislav“, knjižnom inventaru Gradske pučke knjižnice pripojen je preostali knjižni inventar „Tomislava“, kao i sva novčana sredstva dobivena u postupku likvidacije 1927. godine. Iz tog razloga i to društvo možemo smatrati svojevrsnom neizravnom pretečom Gradske knjižnice i čitaonice "Sloboda“, utemeljene poslije II. svjetskoga rata.

3 Razglednica iz Zavičajne zbirke Gradske knjižnice i čitaonice „Metel Ožegović“ Varaždin. 
odluku o promjeni imena društva iz Dvorana u Narodna čitaonica te odabrali Janka Kenfelja za prvog poslijeratnog predsjednika društva. Izvanredna je skupština izmijenjena pravila poslala u Zagreb Zemaljskoj vladi Kraljevine Hrvatske Slavonije i Dalmacije na odobrenje, a ona ih potvrđuje 21. kolovoza 1919. godine.

Nakon što je sto sudionika izvanredne skupštine odabralo predsjednika, određena je i svrha društva - „promicanje društvenosti i općega korisnoga znanja“. 4 Sami je rad Narodne čitaonice bio uređen „Pravilima Narodne čitaonice“ koja su definirala prava i obveze dužnosnika i članova. Članom društva mogla je postati svaka samostalna osoba, bez obzira na stalež, vjeroispovijest i spol, a koja nije nužno morala živjeti u Varaždinu. One osobe koje su željele postati članovima morale su se najprije zapisati u „Knjizi želja“, a odbor je odlučivao hoće li biti primljene ili ne. Ako je za neke osobe $u$ „Knjizi želja“ bilo primjedaba, biralo se posebno povjerenstvo koje je te primjedbe i osobe trebalo istražiti te izvijestiti na sljedećoj sjednici postoji li stvarna zapreka za njihov prijem u članstvo. Time se spriječilo da nepoželjne, neugledne i sumnjive osobe upitna morala postanu članovima Narodne čitaonice pa je članstvo bilo moguće jedino gradskim uglednicima. Svakom novom članu uručivala se pisana pristupnica, a u slučaju da je član htio istupiti iz društva mogao je to učiniti jedino tijekom prosinca, tj. „(...) krajem građanske godine (... “" , dok su se prije kraja godine iznimno mogli ispisati jedino oni koji su napuštali Varaždin. ${ }^{6} U$ „Knjigu želja“, osim građana koji su željeli postati članovima, zapisivale su se i novine, revije i knjige koje su se htjele čitati, prijedlozi članova, ali i pritužbe na postojeće i buduće članove, ponašanje i postupke određenih članova i sl. ${ }^{7}$

\footnotetext{
Rukopisni zapisnik izvanredne skupštine Narodne čitaonice 9. studenoga 1918.

Pravila Narodne čitaonice u Varaždinu, 1918.

Isto.

Isto.
} 


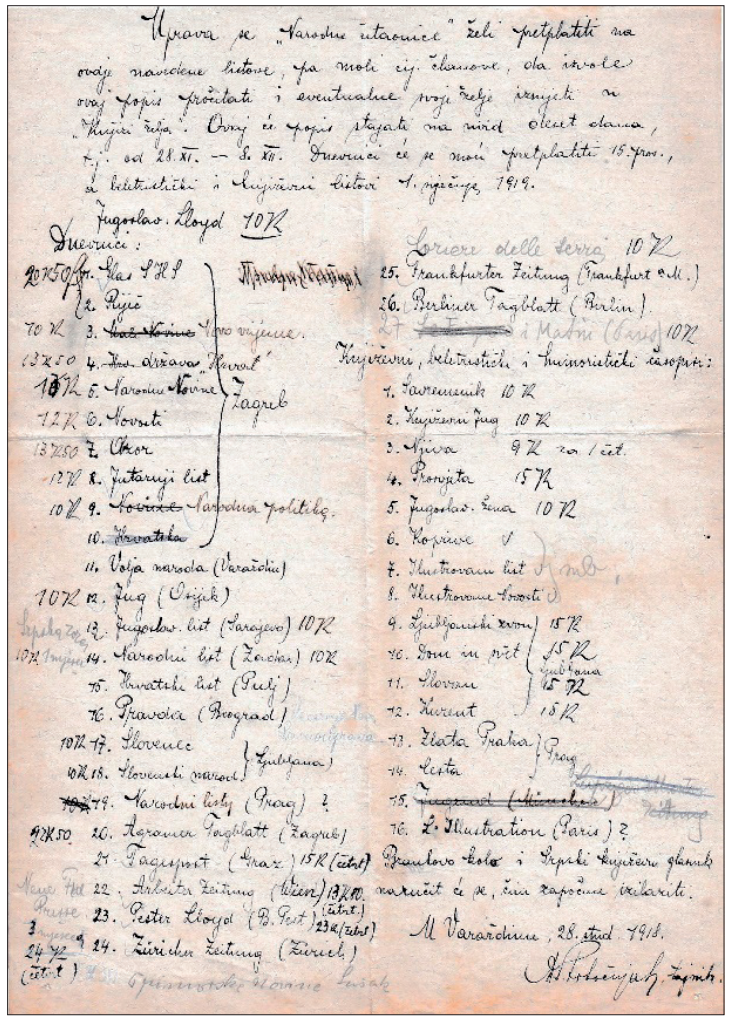

Slika 2. Popis novina i časopisa za „Knjigu želja“ u prosincu 1918. godine ${ }^{8}$

U „Pravilima“ je definirano i koju vrstu aktivnosti i sadržaja „Čitaonica“ nudi svojim članovima - knjige i časopise političkog, beletrističkog te znanstvenog sadržaja, kartaške igre, biljar, šah, koncerte, plesove te poučna predavanja koja su držali ugledni književnici, profesori, kritičari, znanstvenici i doktori. ${ }^{9}$ Svaki je član imao pravo aktivno sudjelovati u određivanju smjera "Čitaonice“ kao i u oblikovanju aktivnosti glasanjem i davanjem prijedloga na izvanrednoj ili redovnoj godišnjoj glavnoj skupštini. Svaki član bio je dužan redovito plaćati mjesečnu članarinu, pridržavati se društvenih „Pravila“ te odluka skupštine i odbora. Cijenu upisnine i članarine određivao je odbor. Članarina je prvenstveno bila namijenjena za nabavu časopisa i knjiga, a upisnina se plaćala jednokratno te je bila namijenjena održavanju pokućstva. Prva članarina iznosila je četiri krune dok je prva

8 Dokumenti sačuvani u Zavičajnoj zbirci Gradske knjižnice i čitaonice „Metel Ožegović“ Varaždin.

9 Pravila Narodne čitaonice u Varaždinu, 1918. 
upisnina bila šest kruna. ${ }^{10}$ Član je mogao biti i izbrisan iz društva ako nije osam dana po primitku opomene o dugu članarine za tri mjeseca istu platio ili ako se oglušio na odluke i zaključke skupštine ili odbora. ${ }^{11}$ Od 12. siječnja 1919. godine u čitaonici je na vidljivom mjestu bio izvješen popis članova Narodne čitaonice. Osim „Knjige želja“ u prostorijama „Čitaonice“ nalazila se i „Knjiga stranaca“ koja je služila za upis gostiju članova, tj. osoba koje nisu bile članovi, ali su ušle u društvene prostorije na poziv članova. ${ }^{12}$
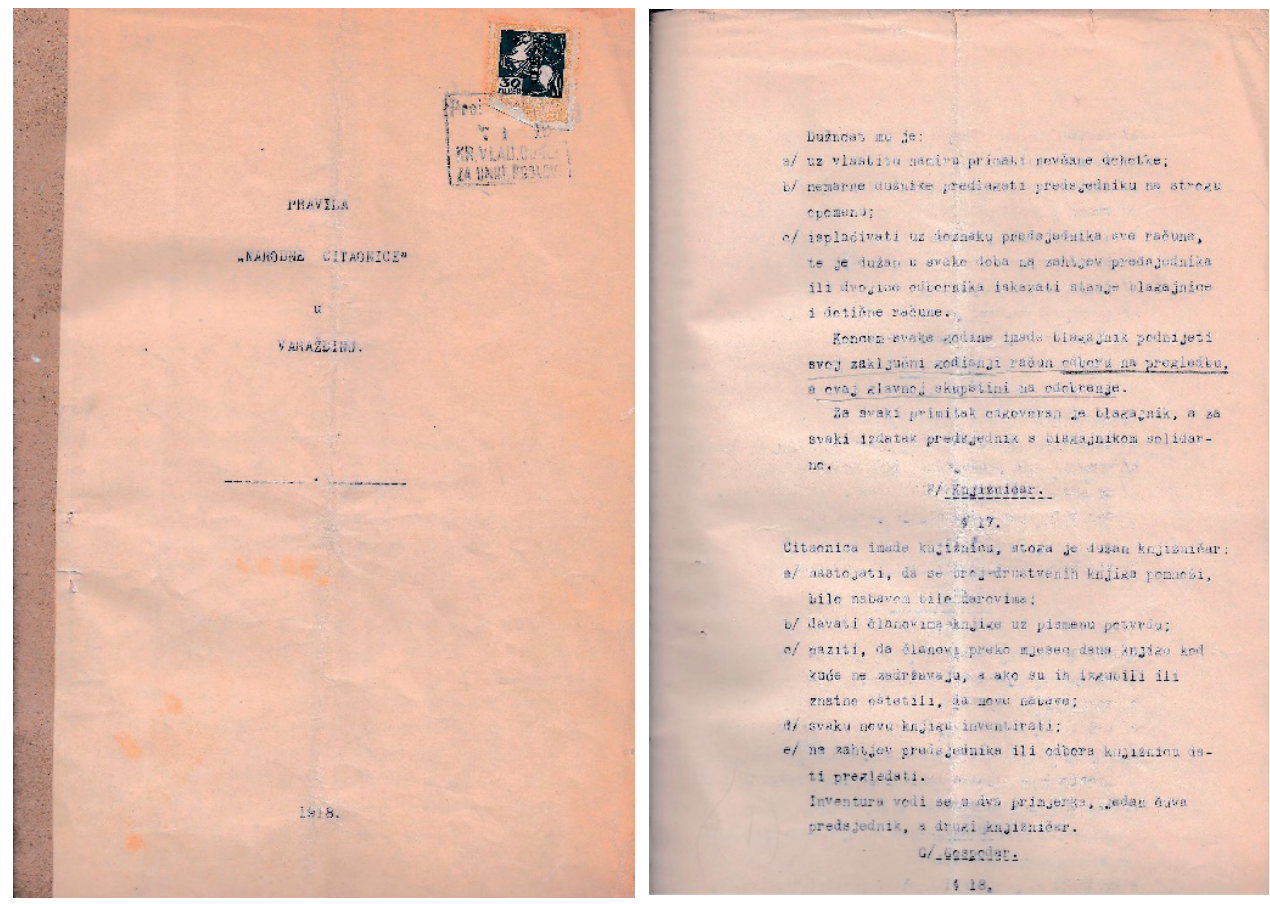

Slika 3. Pravila Narodne čitaonice iz 1918. godine..$^{13}$

„Pravila Narodne čitaonice“ su također definirala postupak i uvjete razilaska društva prema kojima do prestanka postojanja dolazi ako želju za to na skupštini izrazi $3 / 4$ članova te ako društvo raspuste vlasti. Društvena imovina tada prelazi u vlasništvo Gradskoga poglavarstva koje ju čuva tri godine. Ako se u te tri godine

\footnotetext{
10 Isto.

11 Isto.

12 Isto.

13 Dokumenti sačuvani u Zavičajnoj zbirci Gradske knjižnice i čitaonice „Metel Ožegović“ Varaždin.
} 
društvo ponovno ne okupi, Gradsko se poglavarstvo obvezuje imovinu unovčiti te njome potpomognuti siromašne učenike varaždinske gimnazije i pučkih škola. ${ }^{14}$

Upravu Narodne čitaonice sačinjavali su skupština i odbor. lako u „Pravilima“ stoji da se godišnja glavna skupština sastaje svake godine jednom do kraja veljače, ona se najčešće sastajala u ožujku. Izvanredna se skupština sazivala ako se za to ukazala potreba. Svaku skupštinu sazivao je predsjednik osam dana unaprijed, a za donošenje pravovaljanih odluka bila je potrebna nazočnost $1 / 4$ svih članova. U slučaju nedolaska $1 / 4$ članova, nova sjednica sazivala se za osam dana, a na njoj je bilo dovoljno da zaključke i odluke izglasa većina nazočnih članova. Glavna skupština birala je odbor od 14 članova, odlučivala o primanju i isključenju članova, financijama društva, upravi i korištenju društvene imovine, ukidanju prijašnjih odluka, udruživanju s drugim društvima, tj. o svemu ključnom za opstanak društva. Dakle, sva je briga o društvu i nabavi kvalitetne literature za čitanje bila povjerena četrnaestorici odbornika koji su sjednice održavali prema potrebi. Za pravovaljanu je odluku odbora bila potrebna nazočnost predsjednika ili njegova zamjenika te sedmero odbornika. Odbor je među svojim članovima birao društvene dužnosnike - potpredsjednika, tajnika, blagajnika, knjižničara i gospodara te tri člana zadužena za prosvjetne i zabavne aktivnosti, od kojih je jedan morao biti knjižničar. ${ }^{15}$

„Pravila“ su propisivala obveze i djelokrug svakoga dužnosnika Narodne čitaonice te se zahvaljujući njima danas zna što je sve tada obuhvaćalo poslove knjižničara: 1. nastojati da se uveća broj knjiga - bilo nabavom ili donacijama; 2. izdavati knjige uz pisanu potvrdu; 3. voditi brigu da čitači ne zadrže knjigu duže od mjesec dana te tražiti da se oštećene ili izgubljene knjige nadoknade; 4. „inventirati“ nove knjige, 5. dati pregledati knjižnicu na zahtjev predsjednika ili odbora te jedan zapisnik s inventure predati predsjedniku, a drugi zadržati za sebe. ${ }^{16}$

Prva sjednica odbora Narodne čitaonice održala se 16. studenoga 1918. godine. Njome je predsjedao Janko Kenfelj dok je zapisnik vodio Mato Potočnjak. Tom su prigodom izabrani prvi dužnosnici kojima su povjerene aktivnosti u vezi s početkom rada društva. Jednoglasno su izabrani sljedeći dužnosnici: kanonik Milan Kučenjak za potpredsjednika, Mato Potočnjak za tajnika, Miroslav Čabrijan za blagajnika, dr. Antun Krajanski za knjižničara, Bogomil Maltarić za gospodara, a u zabavno-prosvjetni odbor su, osim knjižničara, izabrani Krešimir Filić i Vladimir

\footnotetext{
14 Pravila Narodne čitaonice u Varaždinu, 1918.

15 Isto.

16 Isto.
} 
Janković. Saznajemo da je Narodna čitaonica imala i društvenoga podvornika. U zapisnik ulazi i rečenica kojom se izražava želja za prekidom veza s prošlošću i „birokratsko-militarističkom“ Dvoranom. ${ }^{17} \mathrm{U}$ svezi s time donosi se odluka da se skinu slike bivših predsjednika sa zidova te ih se pogrdno naziva „mađaronima“, „ugnjetavačima“, i „simbolima ropskoga vremena“. Predsjednik na samom kraju sjednice potiče članove da čim prije prionu radu u svom djelokrugu kako bi se društvo ustrojilo i počelo sa svojim aktivnostima.
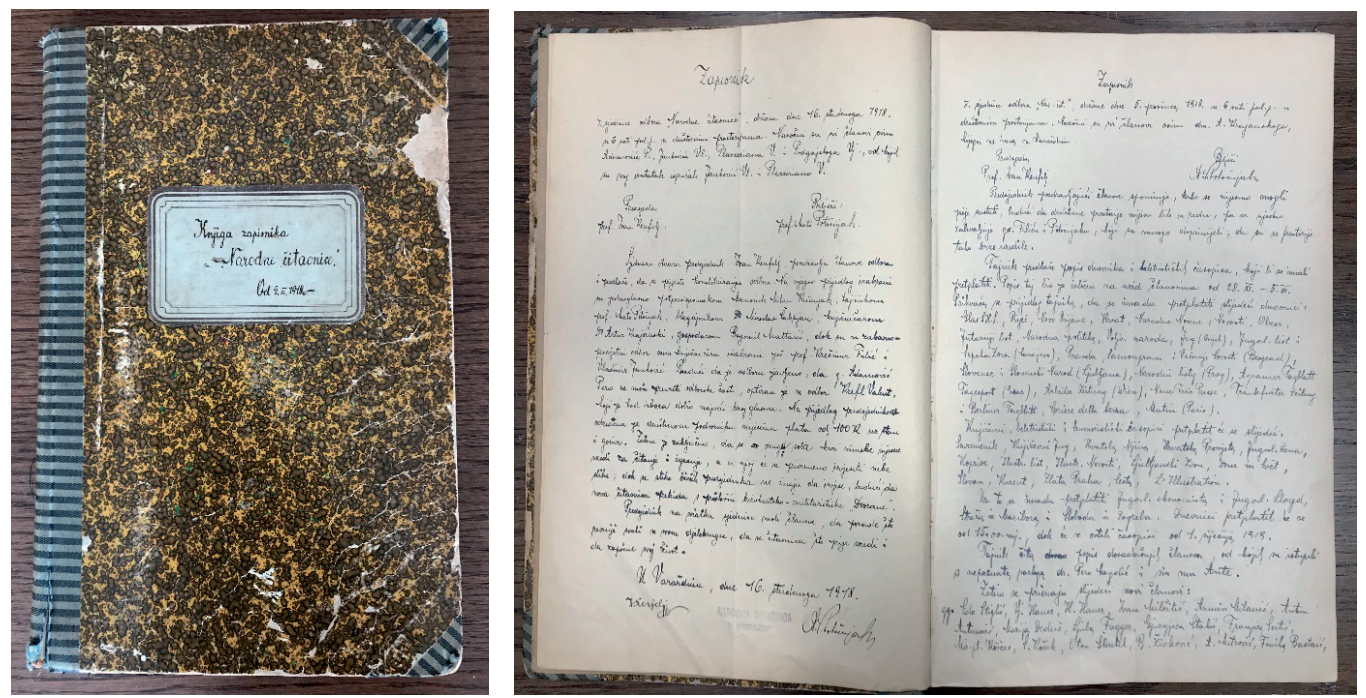

Slika 4. Knjiga rukopisnih zapisnika sjednica odbora, izvanrednih i glavnih skupština Narodne čitaonice. ${ }^{18}$

Iz zapisnika II. sjednice odbora Narodne čitaonice, održane 5. prosinca 1918. godine, saznajemo kako je čitaonica u prvoj godini nakon završetka I. svjetskoga rata bila pretplaćena na sljedeće dnevnike: Glas S.H.S., Riječ, Novo vrijeme, Hrvat, Narodne novine, Novosti, Obzor, Jutarnji list, Narodna politika, Volja naroda, Jug, Jugoslavenski list, Srpska zora, Pravda, Samouprava, Večernje novosti, Slovenec, Slovenski narod, Novi listy, Agramer Tagblatt, Tagespost, Arbeiter Zeitung, Neue Freie Presse, Frankfurter Zeitung, Berliner Tagblatt, Coriere della Serra i Matin.

17 Rukopisni zapisnik sjednice odbora održane 16. studenoga 1918.

18 Dokumenti sačuvani u Zavičajnoj zbirci Gradske knjižnice i čitaonice "Metel Ožegović“ Varaždin. 
Čitaonica je ujedno bila pretplaćena na sljedeće književne, beletrističke i humorističke časopise: Suvremenik, Književni jug, Hrvatska njiva, Hrvatska prosvjeta, Jugoslavenska žena, Koprive, llustrirani list, llustrirane novosti, Ljubljanski zvon, Dom in svet, Slovan, Kurent, Zlata Praha, Cesta, L'Illustration. Te godine „Narodna čitaonica“ bila je pretplaćena na sveukupno 42 novine i časopisa, a u cijelom međuratnom razdoblju toliko veliki ukupni broj literature dosegnut je svega još samo jednom.

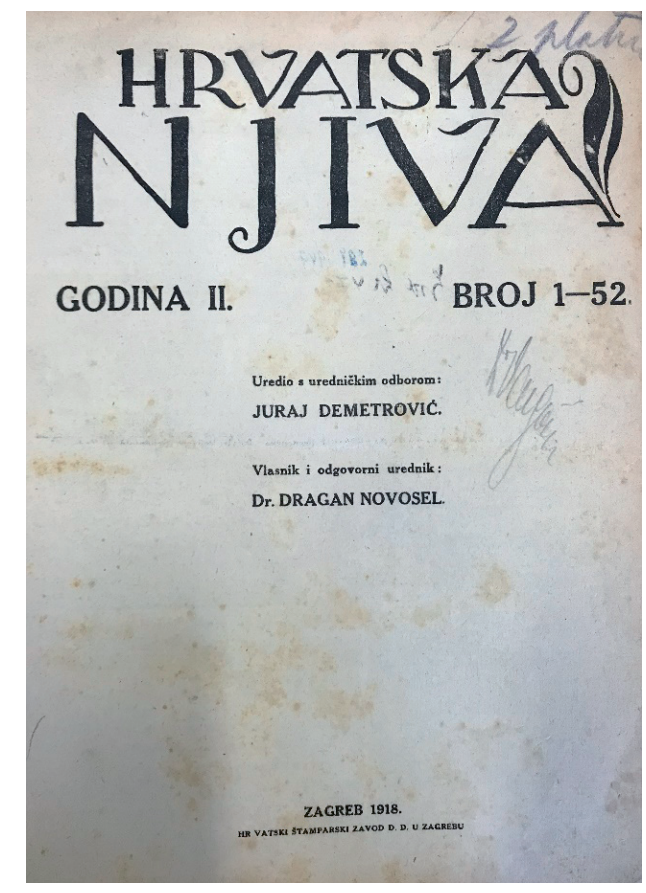

Slika 5. Hrvatska njiva - političko-kulturni tjednik na koji je Narodna čitaonica bila pretplaćena 1918. godine ${ }^{19}$

Neke od novina bile su u „subabonementu“ što je značilo da su ih plaćali određeni članovi te ih stavljali na raspolaganje drugim članovima. Časopisi se u samom početku nisu davali u „subabonement", već su se uvezivali i spremali u knjižnici. Pretplata je za dnevnike tekla od 15. prosinca dok su prvi časopisi stigli tek nakon 1. siječnja 1919. godine. Već na sjednici odbora 30. ožujka 1919. tajnik se žali da se francuske, a i druge strane novine, teško nabavljaju, neredovito dolaze te su k tome još i skupe.

19 Dokumenti sačuvani u Zavičajnoj zbirci Gradske knjižnice i čitaonice "Metel Ožegović“ Varaždin. 
U nekoliko mjeseci nakon završetka „Velikoga rata“, Narodna čitaonica, smještena u zgradi gradskoga kazališta, nije predstavljala samo mjesto gdje članovi dolaze kako bi se čitajući informirali o događajima u zemlji i svijetu, već je bila i središte društvenoga života. Da je Narodna čitaonica postala vrlo posjećeno i popularno mjesto okupljanja gradske elite potvrđuje i zapisnik sa sjednice odbora gdje stoji da pojedini članovi zahtijevaju da se društvena čitaonica preseli u treću sobu jer je nemoguće čitati gdje se igra i razgovara. Čitaonica je bila otvorena do 21 sat, a u njoj se do zatvaranja točilo vino za što je čak ishođena dozvola varaždinske gradske vlasti. Radi stjecanja dodatnog profita, u društvenim prostorijama često su se organizirale zabave s plesom pa se ukazala potreba i za njihovom regulacijom - mogle su se održavati svake druge nedjelje $20-21 \mathrm{~h}$ te se povremeno mogla prirediti literarna ili muzikalna večer. ${ }^{20}$ Članovi su stalno iznosili razne ideje s ciljem unapređenja i još veće popularnosti društva, a o naprednim idejama članova svjedoči, primjerice, podatak da je bilo prijedloga da se već tada uvede telefon, no to nije bilo moguće zbog skupoće priključka. ${ }^{21}$

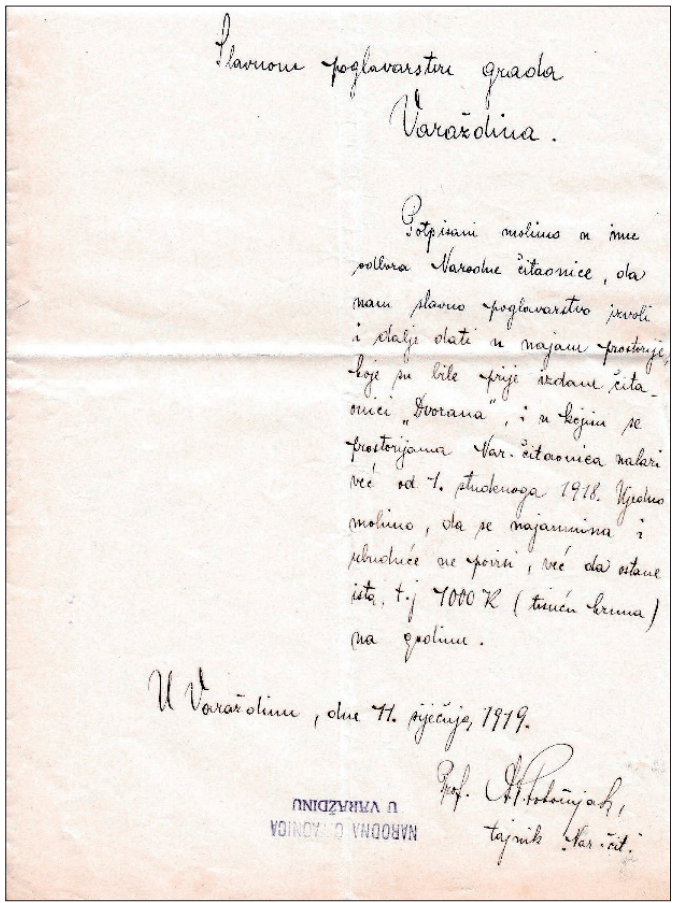

Slika 6. Dopis kojim 11. siječnja 1919. g. tajnik Potočnjak moli Gradsko poglavarstvo da Narodna čitaonica ostane djelovati u prostorijama u sklopu gradskoga kazališta. ${ }^{22}$

20 Rukopisni zapisnik sjednice odbora održane 12. siječnja 1919.

21 Rukopisni zapisnik sjednice odbora održane 5. prosinca 1918.

22 Dokumenti sačuvani u Zavičajnoj zbirci Gradske knjižnice i čitaonice "Metel Ožegović“ Varaždin. 
Odbornik Filić početkom 1919. godine predlaže da se knjige u inventaru društvene knjižnice ustupe Gradskoj pučkoj knjižnici koja će uskoro biti osnovana jer se vrlo malo upotrebljavaju. Nalaže se da se sve knjige popišu i predaju Gradskoj pučkoj knjižnici, no pridržano je pravo vlasništva pa se sve ustupljeno, u slučaju zatvaranja Gradske pučke knjižnice, moralo vratiti „Čitaonici“. S obzirom da je upravni odbor, osim financijske potpore, Gradskoj pučkoj knjižnici predao čitavu knjižnicu (1009 knjiga) i tri ormara na uporabu, Narodna je čitaonica, zajedno s Jugoslavenskim akademskim društvom „Tomislav“ i Gradskim poglavarstvom, bila jedan od njenih osnivača. Sve su se revije Narodne čitaonice krajem godine također uvezale i predale Gradskoj pučkoj knjižnici.

Zbog velike popularnosti ovoga intelektualističkoga društva i njegovih prostorija, već u veljači 1919. g. upućena je molba odboru da dozvoli da se nekoliko puta na tjedan čitaonička soba poslije 21 h koristi za održavanje "Cercle Francaisa“, tj. „Francuskoga kluba“, a odbor to rado prihvaća te želi da čim više članova pristupi učenju francuskoga jezika. ${ }^{23}$

Tijekom 1919. godine Narodna je čitaonica imala 397 članova, a posebno je dobro bila posjećena za zimskih mjeseci. Narodnu čitaonicu nisu posjećivali samo članovi iz grada, već i oni iz prigradskih mjesta pa krajem 1919. godine odbor odobrava produženje rada do $22 \mathrm{~h}$ jer gradska periferija nije imala električne rasvjete, a na taj su način članovi mogli duže boraviti u društvenim prostorijama i čitati.

Ćudoređe je za članove Narodne čitaonice bilo od osobite važnosti pa je odbornik i svećenik Janković već krajem 1919. godine zahtijevao da se u prostorijama Narodne čitaonice zabrane sve hazardne kartaške igre za novac (Macao, Batto i sl.) koje su posebno ugrožavale mlade, a to se nije priličilo jednoj elitističkoj kulturnoj instituciji. Odbor tako zabranjuje sve zakonom zabranjene hazardne igre jer to nije na čast njihovom društvu, a oni koji žele nastaviti te igre, bit će isključeni iz društva.

Prva redovna godišnja glavna skupština Narodne čitaonice održana je 16. studenoga 1918. godine, a druga redovna glavna skupština 22. veljače 1920. godine. Već se na II. glavnoj skupštini ističe zadovoljstvo što su skoro svi dnevnici i revije koje su članovi tražili bili nabavljeni. Međutim, neke su novine dolazile neredovito te se stoga nisu osobito čitale. Posebnih poteškoća bilo je s njemačkim i ostalim stranim dnevnicima koji su bili skupi i dolazili svakih osam dana pa je odbor odustao od pretplate pojedinih novina.

23 Rukopisni zapisnik sjednice odbora održane 8. veljače 1919. 


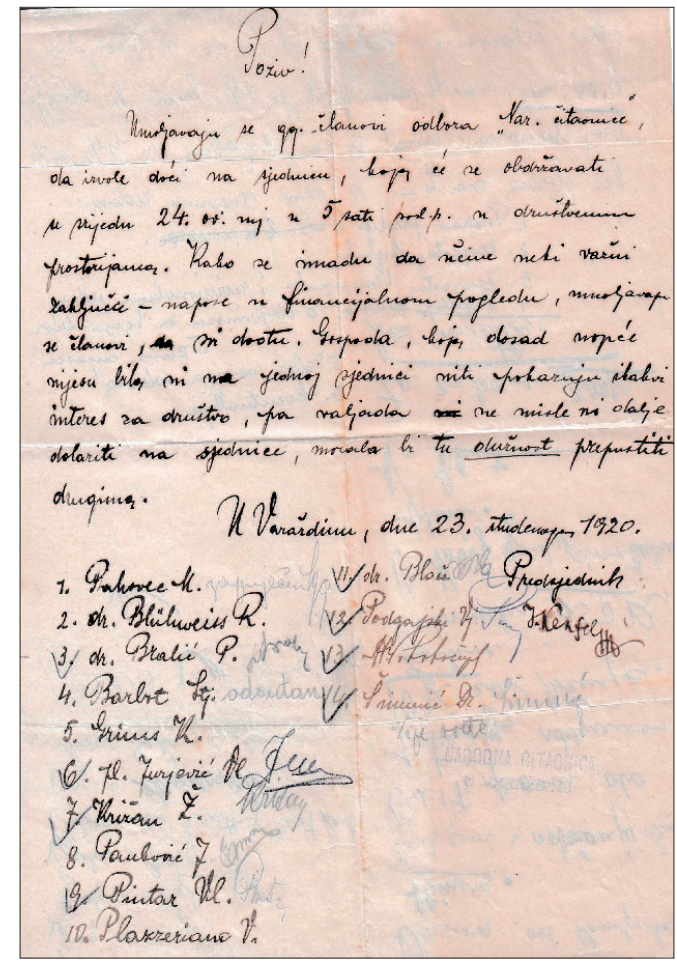

Slika 7. Primjer poziva za odborsku sjednicu Narodne čitaonice u studenom 1920. g. ${ }^{24}$

Financijske poteškoće javljaju se već u drugoj godini poslijeratnoga djelovanja „Čitaonice“ pa se 19. lipnja 1920. godine održava izvanredna sjednica odbora Narodne čitaonice na kojoj predsjednik prikazuje slabo financijsko stanje. Bilo je nemoguće podmirivati sve potrebe s članarinom od četiri krune mjesečno te je odlučeno da se članarina povisi na šest, a upisnina na dvanaest kruna. Štoviše, kroz kratko vrijeme Narodna čitaonica ostaje bez znatnog broja članova koji su rijetko dolazili pa čak i bez onih iz imućnih obitelji. Financijska sredstva moglo se jedino nabaviti organiziranjem zabava i iznajmljivanjem prostorija drugim društvima jer su bile omiljene među građanstvom zbog svoje lokacije tik uz veliku dvoranu varaždinskoga gradskoga kazališta. Pojedini su članovi bili protiv iznajmljivanja prostorija „Čitaonice“ raznim društvima za zabave, ali tajnik naglašava da molbe pristižu sa svih strana te da ih nije moguće odbiti u tolikom broju. U

24 Dokumenti sačuvani u Zavičajnoj zbirci Gradske knjižnice i čitaonice „Metel Ožegović“ Varaždin. 
studenom 1920. godine zbog lošeg financijskog stanja društva i skupoće ogrjeva postojala je mogućnost da će se morati povući u jednu sobu kazališne zgrade. Primorani, uvode prinos za loženje od deset kruna te ukidaju pretplatu nekih listova. Tajnik moli članove da nagovore prijatelje na upis u "Čitaonicu“ kako bi se prikupila sredstva nužna za opstanak društva. Tijekom 1920. godine imali su 300 članova, međutim u vrijeme održavanja redovne godišnje glavne skupštine 1921. godine broje samo 241 člana jer su dodatni članovi istupili iz društva krajem godine. ${ }^{25}$

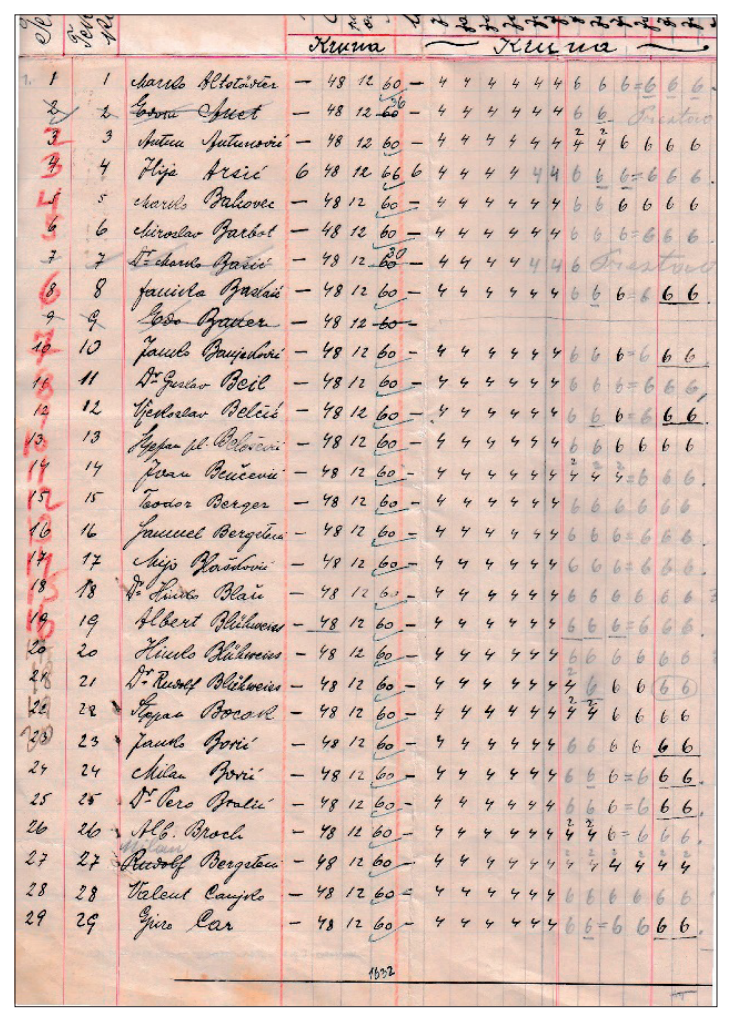

Slika 8. Početna stranica popisa članova Narodne čitaonice iz 1920. godine koja ujedno sadrži podatke o uplaćenim doprinosima i članarini. ${ }^{26}$

Druga odborska sjednica u 1921. godini održana je tek 29. listopada 1921. godine, a sazvana je prvenstveno jer je došlo do nepodopština nepozvanih mladi-

\footnotetext{
25 Riječi tajnika na glavnoj godišnjoj skupštini održanoj 6. ožujka 1921.

26 Dokumenti sačuvani u Zavičajnoj zbirci Gradske knjižnice i čitaonice „Metel Ožegović“ Varaždin.
} 
ća zbog čega je odlučeno da u društvene prostorije pristup imaju samo članovi te se ujedno zabranjuje točenje pića i posluživanje jela u društvenim prostorijama.

Zbog općenito slabih materijalnih prilika u cijeloj državi, već 3. ožujka 1921. godine donosi se odluka da se za vrijeme praznika svim akademičarima odobrava besplatno posjećivanje prostorija Narodne čitaonice i besplatno čitanje novina 13 - 17 sati. Iz tog zapisnika saznajemo da se brojne sazvane odborske sjednice, ali i one glavne skupštine, nisu mogle održati zbog neprisustva dovoljnog broja članova.

Najveća briga društva u 1922. godini i dalje je ona financijske prirode zbog velikog poskupljenja najamnine, goriva, svjetla i pretplata. Budući da se zabave više ne održavaju, prihod donosi jedino članarina i „,kartarina“, no to nije dosta za podmirivanje troškova, tako da se broj novina u pretplati morao umanjiti, čitaonica preseliti u sobu za kartanje, a „kartarina“ povisiti. „Čitaonica“ je bila dobro posjećena u jesen i zimu, no primijećeno je opadanje interesa za društvenost. Na dan 3. ožujka 1922. godine pretplaćuje se osam revija i devetnaest novina s time da su pojedini članovi i „Francuski klub“ također besplatno ustupali neke svoje novine. Svjesni elitističkog i intelektualističkog statusa društva, odbornici su sve pomnije birali novine i časopise koji su se naručivali, tako su, primjerice, odbili pretplatiti se na list Slobodni dom jer su te novine pisale protiv države i činovništva koje je činilo većinu članova Narodne čitaonice. ${ }^{27}$

Od članova se općenito očekivalo da što više revija uzmu u „subabonement“ kako se njihov broj ne bi morao smanjiti nakon povišenja pretplate. One revije koje nisu bile u „subabonementu“, ustupile su se Gradskoj pučkoj knjižnici. Broj članova 6. ožujka 1921. godine je 241, a godinu kasnije, 3. ožujka 1922. godine, ih je samo 214 pa se članovi ponovno mole da u prijateljskom krugu potiču poznanike na učlanjenje jer je to jedini način da se društvo održi.

Na 2. odborskoj sjednici 1922. godine „Francuski klub“ moli da mu se besplatno ustupi prostorija gdje će članovi toga društva moći učiti francuski jezik te postavi jedan ormar za svoju biblioteku. Zauzvrat će „Čitaonici“ besplatno ustupiti francuske novine koje oni imaju u pretplati. Odbor zbog kulturne svrhe toga društva odobrava održavanje satova francuskog dva puta tjedno u vremenu 20 - 22 h u sobi određenoj za biljar. Francuski klub mora plaćati samo troškove rasvjete, čišćenja i u zimi eventualno grijanje. Osim „Francuskome klubu“, prostorije su se povremeno besplatno na uporabu davale za manifestacije s kulturnim i umjetničkim sadržajem.

27 Rukopisni zapisnik sjednice odbora održane 10. ožujka 1922. 
S ciljem podizanja društvenosti među članovima, krajem 1922. godine učitelju plesa Firstu odlučeno je uz naknadu iznajmiti društvenu dvoranu za održavanje škole plesa subotom, ali uz uvjet da vrata moraju biti zatvorena kako se ne bi ometalo rad "Čitaonice“. ${ }^{28}$

Od listopada 1922. godine, članarina se morala povisiti da se najstarije i najotmjenije varaždinsko društvo, tzv. „stjecište sveukupne varaždinske inteligencije", ${ }^{29}$ održi. Nažalost, povišenje članarine najviše je pogodilo upravo članove među koje se nije ubrajao najbogatiji, već najinteligentniji dio varaždinskoga građanstva. Na samom kraju 1922. godine (30. prosinca) održana je licitacija novina te su za iduću godinu gotovo sve novine i revije dane $u$ „subabonement". ${ }^{30}$

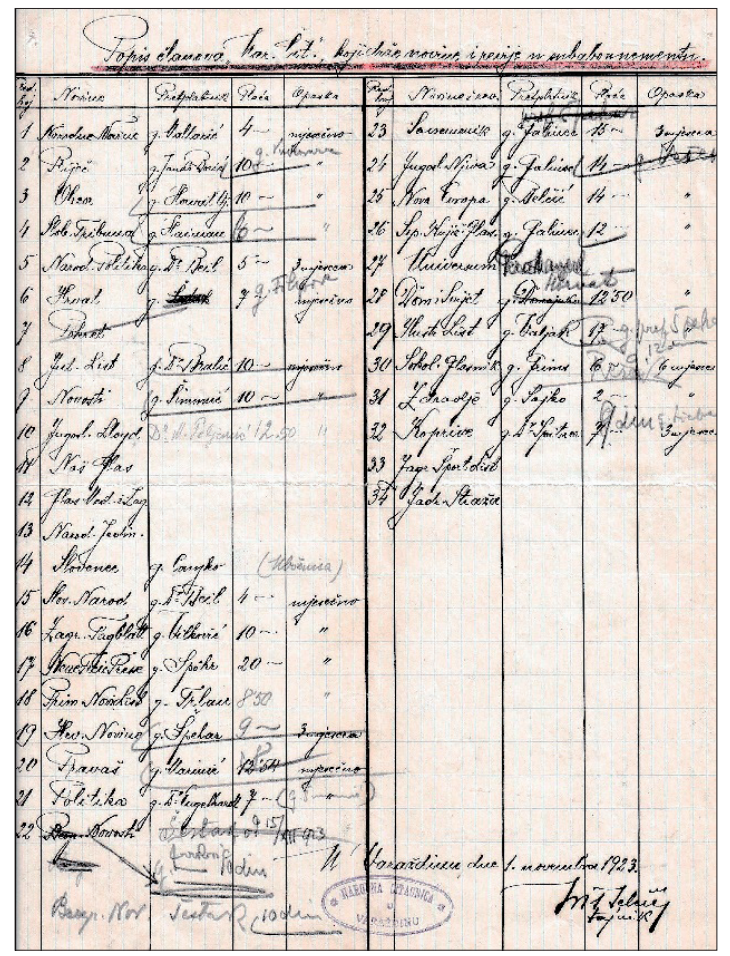

Slika 9. Popis novina i časopisa u „subabonementu“ 1923. godine. ${ }^{31}$

\footnotetext{
28 Rukopisni zapisnik sjednice odbora održane 25. listopada 1922.

29 Rukopisni zapisnik glavne godišnje skupštine održane 18. veljače 1923.

30 Rukopisni zapisnik sjednice odbora održane 30. prosinca 1922.

31 Dokumenti sačuvani u Zavičajnoj zbirci Gradske knjižnice i čitaonice „Metel Ožegović“ Varaždin.
} 
Dakle, „Čitaonicu“ je u njenom funkcioniranju najviše ometalo neprestano poskupljivanje novina, ogrjeva i svjetla. Usprkos tome, zahvaljujući povišenju članarine s deset kruna na deset dinara, mogle su se pretplatiti bolje novine i dobro se grijati pa se zamijetila bolja posjećenost prostorija te interes za društvenost. Štoviše, ponovno se odobrava da knjižnica radi do 22 sata „)(...) što opet omogućuje, da se oni članovi, koji su čitav dan zaposleni, poslije večere sastanu i nađu jeftiniju zabavu nego ma u kojem drugom lokalu“. ${ }^{22}$

Na glavnoj skupštini 1923. godine članovi ističu da je te godine 70. obljetnica izlaska prvih tiskanih „Pravila“ hrvatskog čitaoničkog društva Dvorana i 50. godišnjica dovršenja kazališne zgrade (1873. g.) kad je u njene prostorije smještena „Čitaonica". ${ }^{33}$

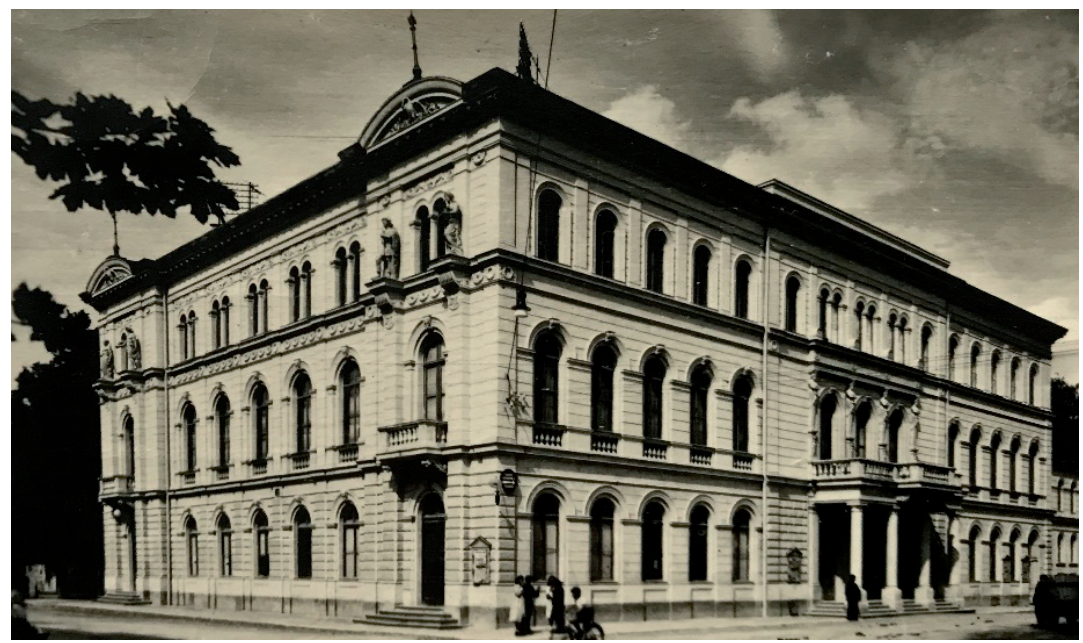

Slika 10. Varaždinska kazališna zgrada u prvoj polovici 20. stoljeća (južna strana). ${ }^{34}$

Već na prvoj odborskoj sjednici 1923. godine, donesena je odluka da se za zabave ne iznajmljuje treća soba koja uvijek mora biti na raspolaganju članovima tako da su nakon dugo vremena članovi te zime imali na raspolaganju sve prostorije Narodne čitaonice. Iz tog razloga se čak odbija molba učitelja plesa Firsta za ustupanje društvene dvorane za održavanje vrlo popularnog tečaja plesa. ${ }^{35}$

\footnotetext{
32 Rukopisni zapisnik glavne godišnje skupštine održane 18. veljače 1923.

33 Isto.

34 Razglednica iz Zavičajne zbirke Gradske knjižnice i čitaonice „Metel Ožegović“ Varaždin.

35 Rukopisni zapisnik sjednice odbora održane 12. lipnja 1923.
} 
Prosvjetni savez iz Zagreba, kojem je Čitaonica pristupila kao prvi član, krajem 1923. godine traži organiziranje analfabetskih tečajeva. Uz članstvo Prosvjetnoga saveza, postojala je želja povezati se i s ostalim kulturnim društvima u domovini jer su u budućnosti planirali brojne aktivnosti na kulturnom polju jer su se do tog vremena uglavnom borili za svoj opstanak. ${ }^{36}$

Početkom prosinca 1923. godine odlučeno je prirediti ples sa zabavnim programom za Silvestrovo, a u siječnju tajnik izvješćuje o njegovom uspjehu te ističe da je zabavi prisustvovao najotmjeniji dio varaždinskoga građanstva. ${ }^{37}$

Blagajnik traži da „Francuski krug“ od 1924. godine plaća neku odštetu za uporabu prostora Čitaonice za održavanje tečaja francuskog jezika pa odbor odlučuje da će morati plaćati 50 dinara mjesečno od 1. siječnja 1924. godine. ${ }^{38}$

U zapisniku se glavne godišnje skupštine, održane 3. veljače 1924. godine, posebno ističe da se tijekom 1923. godine Narodna čitaonica pretplatila na više boljih novina, počelo se popravljati pokućstvo i uvela kvalitetnija rasvjeta. Odbornici na glavnoj skupštini zaključuju da je građanstvo opet zavoljelo Narodnu čitaonicu koja se poslije rata lijepo oporavlja. U vrijeme održavanja redovne godišnje glavne skupštine 1924 . godine pretplaćuje se 25 različitih novina i 13 revija za 225 članova. Te se godine predlaže redukcija broja novina, zatvaranje društvenih prostorija u $21 \mathrm{~h}$ radi smanjenja troškova za svjetlo, povišenje odštete za zabave kao i članarine za pet dinara. Od svakog se člana traži pet dinara više za ogrjev i rasvjetu, a blagajnik mora pozvati članove na uplatu zaostale članarine. ${ }^{39}$

Povremeno je besprijekoran rad ovoga elitističkoga društva narušavalo nekorektno i nepoželjno ponašanje pojedinih članova, no to se uvijek moralno osudilo te pokušalo korigirati. Tako se, primjerice, više puta od tajnika traži da izvjesi obavijest o zabrani pušenja u sobi za čitanje. ${ }^{40} \mathrm{Kad}$ su se jednom prilikom članovi čak potukli prilikom igranja biljara, tajnik je morao izvjesiti obavijest kojom se svi, a posebno mladi članovi upozoravaju na ponašanje u društvenim prostorijama. Odbornici čak odbijaju učlaniti dvojicu Varaždinaca zbog nepristojnog ponašanja. ${ }^{41}$

Početkom 1925. godine naglašava se potreba da knjižničar mora voditi brigu o društvenim knjigama u Gradskoj pučkoj knjižnici i izvijestiti društvo o stanju

\footnotetext{
36 Rukopisni zapisnik sjednice odbora održane 3. prosinca 1923.

37 Rukopisni zapisnik sjednice odbora održane 15. siječnja 1924.

38 Isto.

39 Rukopisni zapisnik glavne godišnje skupštine održane 3. veljače 1924.

40 Rukopisni zapisnik sjednice odbora održane 17. travnja 1924.

41 Rukopisni zapisnik sjednice odbora održane 17. rujna 1924.
} 
društvenih knjiga koje su joj ustupili. ${ }^{42} \mathrm{U}$ kasnije provedenoj reviziji u Gradskoj pučkoj knjižnici ustanovljeno je da nedostaje oko 1.000 knjiga među kojima su bile i brojne knjige Narodne čitaonice. Iz tog razloga odbor nalaže knjižničaru da istraži koliko i koje su društvene knjige tamo nestale. ${ }^{43}$

Iduća glavna skupština Narodne čitaonice s osvrtom na proteklo razdoblje održana je 8. veljače 1925. godine. Na njoj se ističe kako su uspjeli podmiriti sve dugove od kojih je bio najveći onaj za obnovu pokućstva. „Čitaonica“ je kao član pristupila Jadranskoj straži, Jugoslavenskoj matici te otprije ostaje član Prosvjetnog saveza. Tijekom godine pristupilo joj je 76 članova, a istupilo je 98 članova pa čitaonica tada broji 203 člana te plaća pretplatu za 21 novine i 13 revija. U „subabonementu“ članovi drže jedanaest novina i osam revija. Od knjiga su kupljena dva sveska Almanaha S.H.S. od kojih je prvi dio nestao, a potraga za njegovim pronalaskom završava neuspješno. Povisuje se članarina na petnaest dinara mjesečno. Zbog nedovoljnog odziva članova na godišnju glavnu skupštinu, mijenja se zadnji stavak 11. odlomka „Pravila“. Dotad je bilo propisano da ako se ne sastane $1 / 4$ članova, mora se u roku od 8 dana sazvati nova skupština, no izmjenom toga članka omogućeno je da se u tom slučaju skupština sastane $1 \mathrm{~h}$ kasnije bez obzira na broj prisutnih članova. ${ }^{44}$

Na sjednici odbora u svibnju 1925. godine članovi su suglasni da se prostorije Narodne čitaonice obnove, tj. oboje, a podovi ulašte. Za obnovu su tražili financijsku pomoć od grada „(...) jer će od uređenja društvenih prostorija imati i grad koristi, budući da ih može upotrijebiti u reprezentativne svrhe“. 45

Zapisnik odborske sjednice Narodne čitaonice održane 15. listopada 1925. godine otkriva nam političko usmjerenje njenog tadašnjeg vodstva: „Na razne želje, izražene u Knjizi želja zaključuje se, da se više neće držati Slovenec, a ne udovoljava se željama, da se Nar. čitaonica pretplati na Wiener Bilder ili Interessantes Blatt jer Beč nije više za nas centar, kao prije 29. listopada 1918., a u Narodnoj čitaonici ima odličnih francuskih revija."

Nažalost, događaju se „literarne krađe“, tj. nestaju revije iz čitaonice, a članovi se trude pronaći krivca dok se „(...) podvorniku obećava „uhvatnina“ od 100 dinara“. ${ }^{46}$ Veliki problem Narodne čitaonice i dalje predstavljaju financije te se iz zapisnika može iščitati koliko je bilo loše financijsko stanje: „Blagajnik tužnim,

\footnotetext{
42 Rukopisni zapisnik sjednice odbora održane 17. veljače 1925.

43 Rukopisni zapisnik sjednice odbora održane 18. siječnja 1926.

44 Rukopisni zapisnik glavne godišnje skupštine održane 8. ožujka 1925.

45 Rukopisni zapisnik sjednice odbora održane 26. svibnja 1925.

46 Rukopisni zapisnik sjednice odbora održane 15. listopada 1925.
} 
skoro očajnim glasom izvješćuje o žalosnom stanju društvene blagajne. Na njemu se vidi da mu ta tuga ide od srca. Odbor ga tješi.“" ${ }^{\text {"7 }}$

Na samom početku 1926. godine zbog pritužbi članova da djeca koja pohađaju tečaj francuskoga u „Francuskome klubu“ ometaju članove kod igranja biljara, kartanja i čitanja, molilo se predsjednika toga društva, dr. Vračuna, da se đački tečaj preseli u jednu od škola na što je on i pristao. Nadalje, dr. Vračun traži da se uvedu ciklusi predavanja iz suvremene hrvatske, slovenske i srpske književnosti po uzoru na francuske čitaonice. ${ }^{48}$

Na glavnoj godišnjoj skupštini 7. ožujka 1926. godine ustanovljeno je da je broj članova znatno pao. „Uzrok istupu mnogih članova je pomanjkanje zabava zbog nestašice novaca, pa će u tom pogledu novi odbor trebati da nađe sredstva kojima će vezati uz čitaonicu i članove, što ne dolaze redovno na čitanje novina. ${ }^{49}$ Te godine za čitanje na raspolaganju stoji čak 25 novina i 17 revija. ${ }^{50}$

Na listopadskoj sjednici 1926. godine zbog neredovitog održavanja odborskih sjednica odbornici zaključuju kako bi se one trebale održavati jednom mjesečno. Broj članova dalje pada jer u građanstvu „nestaje potrebe i interesa za čitaonicu“. ${ }^{51}$ Da se pobudi interes kod građanstva, priređivala su se za članove predavanja iz književnosti, trgovačkih i financijskih znanosti. Nadalje, pozvali su se časnici da u što većem broju postanu članovi. ${ }^{52}$ Kad krajem 1926. godine Šahovski klub moli da im se ustupe prostorije Narodne čitaonice za njihove potrebe, odbor zaključuje da se članovi Šahovskog kluba prvo učlane u čitaonicu pa će onda moći u njoj i igrati, a sve s ciljem povećanja broja članova. ${ }^{53} \mathrm{U}$ prosincu 1926. godine odlučuje se da odbornici mogu samostalno odlučivati o ustupanju prostorija za zabave - bez dozvole cijeloga odbora. ${ }^{54}$ Zahvaljujući toj odluci uspjelo se povećati prihode pa su članovi bili tolerantni prema svima koji su koristili društvene prostorije, a nisu bili članovi. ${ }^{55} \mathrm{U}$ zapisniku sjednice odbora od 26. travnja 1927. godine stoji da se odobrava ustupanje društvenih prostorija čak za čajanku maturanata. Mjesec dana kasnije odbornici besplatno ustupaju

\footnotetext{
47 Isto.

48 Rukopisni zapisnik sjednice odbora održane 18. siječnja 1926.

49 Rukopisni zapisnik glavne godišnje skupštine održane 7. ožujka 1926.

50 Isto.

51 Rukopisni zapisnik sjednice odbora održane 21. listopada 1926.

52 Isto.

53 Rukopisni zapisnik sjednice odbora održane 12. studenoga 1926.

54 Rukopisni zapisnik sjednice odbora održane 16. prosinca 1926.

55 Rukopisni zapisnik glavne godišnje skupštine održane 10. travnja 1926.
} 
prostorije za zabave učenicima građanske škole i čakovečkoj preparandiji zbog toga što su te priredbe bile kulturnog karaktera, a prihod namijenjen putovanju đaka. Besplatno ustupaju prostorije i Pjevačkom društvu „Tomislav“ kako bi oni obilježili svoju 10-godišnjicu postojanja. ${ }^{56}$

Šahovskom se klubu, nakon ponovne molbe, u listopadu 1927. godine do ožujka 1928. godine odobrava uporaba treće sobe svake nedjelje i utorka, ako ti termini ne kolidiraju s onima „Francuskoga kluba“. ${ }^{57}$

Na Silvestrovo 1927. godine prostorije se tad već tradicionalno ustupaju Pjevačkom društvu „Tomislav“ za priredbu novogodišnje zabave. Dr. Milković u prosincu moli da se Francuskom klubu dozvoli u sobu smjestiti klavir kojim bi se i Narodna čitaonica mogla služiti za neznatnu odštetu te bi mogli zajedno davati kućne zabave. Odbor odobrava postavljanje klavira samo za zabave, a u ostalo se vrijeme mora držati pod ključem. ${ }^{58}$

Na sjednici upravnog odbora u siječnju 1928. godine pojedini se članovi žale na odnošenje novina iz prostorija Narodne čitaonice te na nedolično ponašanje pojedinih mlađih članova kod igranja biljara i kartanja. Zbog toga su ponovno tiskani oglasi kojima se oštro osuđuje i zabranjuje takvo ponašanje. Odlučeno je 90-godišnjicu Narodne čitaonice proslaviti u Korizmi „(...) kada ne bude toliko plesova (...)“ što znači da su ponovno bili primorani često iznajmljivati svoje prostorije radi stjecanja prihoda. ${ }^{59} \mathrm{Na}$ Uskrsni ponedjeljak 1928. godine, povodom obilježavanja 90-godišnjice Narodne čitaonice, prof. Galinec držao je kratko predavanje o povijesti Narodne čitaonice. Za vojnu se muziku pobrinuo potpredsjednik Mićić, a glazbeni dio izveli su članovi Pjevačkoga društva „Tomislav“ nakon čega je održan ples. ${ }^{60}$

\footnotetext{
56 Rukopisni zapisnik sjednice odbora održane 30. svibnja 1927.

57 U zapisniku od 20. listopada 1927. godine još se ističe da ne smiju donašati piće i nemaju pristupa u prve dvije sobe, a jedan stariji član Šahovskoga kluba mora nadzirati đake kad igraju šah. Plaćaju 200 dinara mjesečno za svjetlo i čišćenje, a ogrjev su dužni nabavljati si sami te su odgovorni za inventar i zidove.

58 Rukopisni zapisnik sjednice odbora održane 10. prosinca 1927.

59 Rukopisni zapisnik sjednice odbora održane 27. siječnja 1928.

60 Rukopisni zapisnik sjednice odbora održane 2. ožujka 1928.
} 


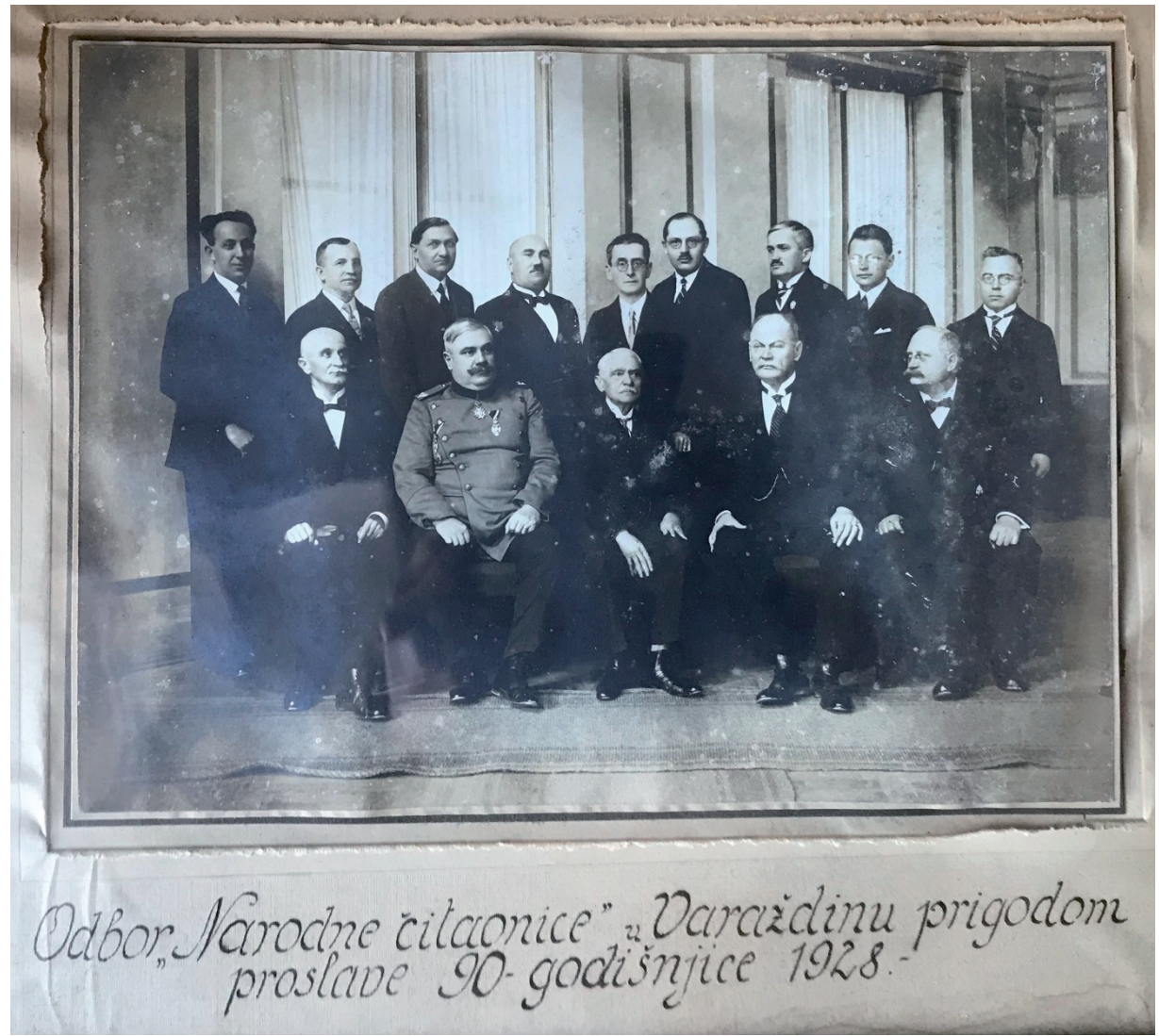

Slika 11. Fotografija odbornika prigodom proslave 90-godišnjice Narodne čitaonice 1928. g. ${ }^{61}$

Na redovnoj godišnjoj glavnoj skupštini 11. ožujka 1928. godine utvrđeno je kako se protekle godine broj članova nešto povećao, kao i broj novina i revija. Iz redovnih primanja renovirali su dio inventara te obnovili izgled prostorija. Blagajnik izvještava da je blagajničko poslovanje teklo povoljno za Narodnu čitaonicu te naglašava da sve stoji detaljnije u „Blagajničkoj knjizi“. Tako saznajemo da su se financije detaljno vodile pismeno, no „Blagajnička knjiga“ do danas nije pronađena. Predsjednik Kenfelj i na ovoj sjednici potiče članove da promoviraju čitaonicu među svojim poznanicima i u 1928. godini kako bi se privukli novi članovi. ${ }^{62}$

61 Dokumenti sačuvani u Zavičajnoj zbirci Gradske knjižnice i čitaonice „Metel Ožegović“ Varaždin.

62 Rukopisni zapisnik godišnje glavne skupštine održane 11. ožujka 1928. 
Potkraj studenoga 1928. godine udovoljilo se želji brojnih članova da prestanu držati novine Slovenec i Samouprava „(...) zbog vrijeđanja hrv. naroda (...)“, a što je uzrokovalo nezadovoljstvo pojedinih članova. Štoviše, na odborskim sjednicama i među članovima povremeno dolazi do prepucavanja zbog različite političke opredijeljenosti. Na toj se sjednici vodi redovna debata o krađi novina i revija, a profesor Galinec predlaže da Narodna čitaonica preuzme natrag svoje knjige i ormare iz Gradske pučke knjižnice kako bi uredili svoju knjižnicu u prostorijama Narodne čitaonice. Odbor odlučuje preuzeti one knjige koje se ne posuđuju u Gradskoj pučkoj knjižnici te im samo smetaju u njihovom skučenom prostoru. Taj posao obavio je knjižničar prema sporazumu s gradskom knjižnicom. ${ }^{63}$

Na redovitoj glavnoj godišnjoj skupštini 1929. godine naglašava se da se u sklopu Narodne čitaonice ponovno počela organizirati knjižnica. Glavna skupština odlučuje da se 1.000 dinara upotrijebi za nabavu knjiga za društvenu knjižnicu. ${ }^{64}$ Dr. Milković dobiva mandat da sastavi poseban pravilnik za knjižnicu Narodne čitaonice. Iz Gradske se pučke knjižnice do sredine studenoga 1929. godine vratilo 300 knjiga, a kad je vraćen i ormar, knjige su se sortirale te iznova „,inventirale“. Odlučeno je da će se knjige posuđivati na 14 dana uz pismenu potvrdu. ${ }^{65}$

Negativan trend smanjenja broja članova nastavlja se i u 1930. godini kad tajnik na glavnoj skupštini izvještava članove da je broj članova pao sa 193 na 164 , a cijele su godine održane samo tri odborske sjednice. Držalo se 22 novine i 12 revija. Iz gradske su knjižnice vraćene 542 knjige te kupljeno dosta novih pa tada društvena knjižnica ima 756 knjiga. Kako bi uspješno povećali broj članova, istaknuto je da su za tu svrhu potrebne zabave pa se predlaže da mladi članovi sastave poseban zabavni odbor za priredbu zabava pod nazivom „Mali koncerti, deklamacije, ples“ pri čemu se osobito preporučuje njegovanje narodnih plesova. ${ }^{66}$

S obzirom da se postepeno broj članova i dalje smanjuje, odbornici u listopadu 1930. godine donose odluku obratiti se svim uredima i društvima s apelom da u svojoj sredini prikupe članove. Nadalje, zbog molba članova društvene će prostorije biti otvorene do 22 sata navečer. Knjižničar izvješćuje da će se pristupiti uređenju knjižnice, odnosno njenoj katalogizaciji te će se nakon toga knjige posuđivati članovima. ${ }^{67}$

\footnotetext{
63 Rukopisni zapisnik sjednice odbora održane 20. studenoga 1928.

64 Rukopisni zapisnik godišnje glavne skupštine održane 10. ožujka 1929.

65 Rukopisni zapisnik sjednice odbora održane 14. ožujka 1929.

66 Rukopisni zapisnik godišnje glavne skupštine održane 16. ožujka 1930.

67 Rukopisni zapisnik sjednice odbora održane 15. listopada 1930.
} 
Zapisnik godišnje glavne skupštine 1931. godine otkriva kako su održane samo dvije odborske sjednice u proteklom razdoblju. Društvo ima 160 članova pa se smatra kako je potez slanja dopisa uredima i društvima urodio plodom jer su gotovo svi članovi koji su se ispisali nadomješteni novima. Pretplaćuju 19 novina i 11 revija. Knjižničar je izvijestio da je u prosincu u potpunosti uređena knjižnica, knjige su katalogizirane, a postoje dva kataloga. Tijekom godine nabavljene su 62 knjige, a knjižničar moli da se dodatno poveća proračun za knjižnicu. ${ }^{68}$

Zbog loše financijske situacije blagajnik predlaže da se u 1931. godini ukine po 1 primjerak najčitanijih listova Novosti i Jutarnjeg lista budući da je broj članova smanjen. Te je godine povišena najamnina „Francuskom klubu“ sa 75 dinara na 100 dinara, a ubuduće se ni jednom društvu neće besplatno izdavati prostorije. Sva društva koja u čitaoničkim prostorijama održavaju odborske sjednice od 1. listopada do 1. travnja moraju plaćati deset dinara za rasvjetu i ogrjev. ${ }^{69}$

Tajnik na odborskoj sjednici u ožujku 1931. godine predlaže osnivanje fonda za proslavu društvene stogodišnjice 1938. godine te ujedno ističe potrebu pravovremenog prikupljanja sredstava za takav jedan značajan i rijedak jubilej. Budući da proslava mora imati dostojan i kulturan oblik, jasno je da neće biti lako prikupiti potrebna novčana sredstva. Odbornici osnivaju fond za prikupljanje sredstva uz napomenu da se taj fond neće moći koristiti u druge svrhe, a godišnje se obvezuju ulagati najmanje 1.500 dinara na knjižicu u Gradskoj štedionici. Društvo je za tu prigodu osiguralo i primitak subvencije od gradske općine u iznosu od 1.000 dinara godišnje. $^{70}$

Na godišnjoj glavnoj skupštini 1932. godine konstatirano je da su održane samo dvije sjednice odbora Narodne čitaonice. Društvo broji 150 članova što znači da je broj članova pao za deset, a „što se imade pripisati sniženju plaća i bijednom stanju činovnika". ${ }^{11}$ Pretplaćeni su na 18 novina i 10 časopisa te se ističe da je, usprkos smanjenim materijalnim sredstvima, članstvu na raspolaganje ostao znatan i lijep broj novina i časopisa. U kolovozu 1931. godine izvršena je revizija knjižnice te je ustanovljeno da ni jedna knjiga nije nestala niti je oštećena. Napominje se da je interes za čitanje među članovima znatan pa je redovito polovica knjiga beletrističkog sadržaja bila posuđena. ${ }^{72}$

\footnotetext{
68 Rukopisni zapisnik godišnje glavne skupštine održane 15. ožujka 1931.

69 Rukopisni zapisnik sjednice odbora održane 24. ožujka 1931.

70 Rukopisni zapisnik sjednice odbora održane 28. veljače 1932.

71 Rukopisni zapisnik godišnje glavne skupštine održane 20. ožujka 1932.

72 Isto.
} 
Na glavnoj se skupštini 26. ožujka 1933. godine ponovno ističe kako su održane samo dvije sjednice odbora u protekloj godini na kojima su se rješavala tekuća pitanja. Tajnik upozorava na približavanje stogodišnjice društva, naglašava da se ona mora svečano proslaviti što će biti moguće jedino složnim radom i ako se unaprijed osiguraju „(...) makar skromna novčana sredstva“. ${ }^{73}$ Društvo ima samo 127 članova, a prošle godine ih je bilo 159 pa se napominje da je to značajan pad. Usprkos tome društvo prima ukupno 31 novine i časopis - „što je razmjeran broj i omogućuje članovima dovoljnu i mnogostranu lektiru“. ${ }^{74}$ Knjižnica je povećana redovitim i izvanrednim izdanjima Matice hrvatske, svim izdanjima Srpske književne zadruge i onima 1.000 najljepših pisaca. Nabavljene su i pojedine knjige boljih pisaca različitih zaklada. U knjižnici se pohranjuju i sve revije i časopisi koji se krajem godine uvezuju. ${ }^{75}$

Između 95. i 96. glavne skupštine održana je samo jedna odborska sjednica. Na 96. godišnjoj redovnoj glavnoj skupštini 1934. godine društvo broji 148 članova kojima su sveukupno dostupne 32 novine i časopisa. U siječnju su priredili kućnu zabavu s plesom te koncert čelista Šedlhauera. Na toj skupštini dolazi do promjene dužnosnika - potpredsjednik postaje Edo Filipović, a knjižničar Branimir Lypolt. ${ }^{76}$

U listopadu 1934. godine na sjednici odbora, koja je zapravo bila komemoracija Kralju Aleksandru I., u zapisniku je kao predsjednik potpisan okružni sudac Filipović, a on je održao i govor veličajući ubijenoga kralja Jugoslavije. Knjižnica, ove godine, osim uobičajenih izdanja, odlučuje nabavljati djela „Minerva - 100 godina hrvatske književnosti“ te sveukupna djela Turgenjeva (20 knjiga), a nabavljen je i leksikon „Minerva“. ${ }^{77}$

Doznajemo da potpredsjednik Filipović ponovno vodi sjednicu u veljači 1935. godine zbog uznapredovale bolesti dotadašnjega dugogodišnjega predsjednika Janka Kenfelja. ${ }^{78}$

Zapisnik redovne godišnje glavne skupštine 1935. godine svjedoči o porastu broja članova u proteklom razdoblju - čitaonica tad ima ukupno 160 članova. Držali su svega 33 novine i časopisa. Knjižnica je povećana za 42 knjige te ih sada ima ukupno 794. Izgubljene su bile dvije knjige, no one su nadoknađene novima. ${ }^{79}$

\footnotetext{
73 Rukopisni zapisnik godišnje glavne skupštine održane 26. ožujka 1933.

74 Isto.

75 Isto.

76 Rukopisni zapisnik godišnje glavne skupštine održane 25. ožujka 1934.

77 Rukopisni zapisnik sjednice odbora održane 18. listopada 1934.

78 Rukopisni zapisnik sjednice odbora održane 3. veljače 1935.

79 Rukopisni zapisnik godišnje glavne skupštine održane 3. ožujka 1935.
} 
Na dan smrti preminulog društvenog predsjednika Janka Kenfelja, koji je preminuo u 82. godini života, 10. svibnja 1935. godine, održana je sjednica odbora njemu u spomen. Izabran je bio odmah po formiranju društva nakon I. svjetskog rata te je tu dužnost vršio neprekidno do svoje smrti. ${ }^{80}$

Zbog izbora novoga predsjednika 29. rujna 1935. godine održana je izvanredna godišnja skupština koja za predsjednika bira Krešimira Filića. On se tom prilikom obratio okupljenim članovima te naglasio da je pristao prihvatiti predsjedničku čast nakon dugog nagovaranja te da će složno raditi s ostalim članovima na „(...) procvatu ove najstarije kulturne institucije grada Varaždina“. ${ }^{11}$ Također je izrazio uvjerenje da će svoju zadaću moći izvršavati uspješno i korisno jedino uz punu potporu i razumijevanje svih članova. ${ }^{82}$

Na odborskoj sjednici u listopadu 1935. godine odlučeno je da će Narodna čitaonica početi redovito održavati koncerte izašavši u susret željama ljubitelja glazbe. Budući da je za to bio potreban klavir, odlučuju kupiti jedan marke „Minoza“ po cijeni od 10.000 dinara. Tako su u zimskoj sezoni 1935./1936. bili priređeni koncerti „Kvarteta glazbenog društva intelektualaca“, pijanista Petra Dumičića, čelista Čeda Šedlhauera i basista Lava Vrbanića. ${ }^{83}$

Za uporabu klavira izdan je i od strane odbora prihvaćen „Pravilnik za klavir“ koji je tajnik sastavio 23. listopada 1935. godine. Pravilnik je imao devet točaka te točno određivao sav postupak s društvenim klavirom. ${ }^{84}$ Međutim, nakon nekoliko mjeseci su članovi Narodne čitaonice ustanovili da je klavir dobar za privatne svrhe, ali nažalost ne odgovara za izvedbu koncerata te postoji potreba za nabavom koncertnoga klavira. Odbor zbog toga odlučuje prodati klavir kupljen prošle godine te kupiti novi po cijeni od najviše 30.000 dinara. ${ }^{85}$ Predsjednik i blagajnik razgledali su mnoge stare i nove klavire u Zagrebu te se nakon savjetovanja sa stručnjakom, prof. Petrom Dumičićem, odlučili za kupnju klavira „Ed. Seiler" po cijeni od 27.500 dinara. Prvi društveni koncert i „kolandacija“ novog klavira bila je u subotu, 23. siječnja 1937. godine. Upravo je profesor Petar Dumičić iz Zagreba održao prvi koncert na njemu, nakon čega je svaki mjesec održan po jedan koncert. ${ }^{86}$

80 Rukopisni zapisnik sjednice odbora održane 10. svibnja 1935.

81 Rukopisni zapisnik izvanredne glavne skupštine održane 29. rujna 1935.

82 Isto.

83 Rukopisni zapisnik sjednice odbora održane 7. listopada 1935.

84 Rukopisni zapisnik sjednice odbora održane 16. ožujka 1936.

85 Rukopisni zapisnik sjednice odbora održane 26. studenoga 1936.

86 Rukopisni zapisnik sjednice odbora održane 18. siječnja 1937. 
Na 99. glavnoj skupštini predsjednik Filić potiče prisutne da u najvećoj mogućoj mjeri porade na povećanju broja članova kako bi se kulturno djelovanje pojačalo „pa da čitaonica bude doista kulturno žarište Varaždina“. ${ }^{87}$ Čitaonica tada ima 146 članova te je pretplaćena na 35 časopisa i novina što znači da se te godine njihov broj povećao.

U godinu dana broj se knjiga u društvenoj knjižnici povećao za $48 .^{88} \mathrm{U}$ zapisniku sa sjednice glavne skupštine 1937. godine po prvi puta pronalazimo podatak o podjeli knjižne građe (816 knjiga) Narodne čitaonice u sedam struka. Tako je na dan 20. ožujka 1937. godine prema strukama stanje knjižnice bilo sljedeće: 89

1. Revije, almanasi i enciklopedije (202 knjige), 2. Romani, novele i crtice (324 knjige), ${ }^{90} 3$. Povijest književnosti i umjetnosti (78 knjiga), 4. Historija, arheologija, geografija (148 knjiga), 5. Filozofija i socijalne znanosti (36 knjiga), 6. Prirodne nauke (25 knjiga), 7. Različito (3 knjige).

Od siječnja do svibnja 1937. godine društvo je priredilo sedam koncerata odlična uspjeha te odbor ovlašćuje predsjednika i tajnika da provedu pripreme za koncertnu sezonu 1937./1938. u kojoj je svakoga mjeseca bilo planirano održavanje jednog koncerta. ${ }^{91}$ Do 2 . travnja 1938. godine društvo je priredilo osam koncerata istaknutih glazbenika koji su izvodili djela najboljih skladatelja. Izvan programa koncert je održala i sopranistica Lela Trbuhović. ${ }^{92}$

Uoči proslave stogodišnjice Narodna čitaonica nije od Gradskog poglavarstva dobila pomoć za provedbu potrebne adaptacije društvenih prostorija pa su o svom trošku uredili strop u srednjoj dvorani i u sobi „Francuskog kluba“ te postavili glinene peći umjesto dotadašnjih željeznih radi boljeg zagrijavanja društvenih prostorija. Odaslali su cirkular uglednim građanima za pristup u društvo nakon čega mu je pristupilo dodatnih 20 članova. Blagajnik izvješćuje da je financijsko stanje društva povoljno dok dug za klavir otplaćuju redovno i u većim iznosima nego što je predviđeno..$^{93}$

Na stotoj glavnoj godišnjoj skupštini 26. ožujka 1938. godine prisustvuje 96 članova te izaslanik vlasti, policijski „(...) agent Josip Koželj“! ${ }^{94}$ Filića veseli tako

\footnotetext{
87 Rukopisni zapisnik godišnje glavne skupštine održane 21. ožujka 1937.

88 Isto.

89 Isto.

90 Ova ista struka iduće je godine nazvana „Romani, novele i pjesništvo“.

91 Rukopisni zapisnik sjednice odbora održane 28. svibnja 1937.

92 Rukopisni zapisnik godišnje glavne skupštine održane 26. ožujka 1938.

93 Rukopisni zapisnik sjednice odbora održane 6. prosinca 1937.

94 Rukopisni zapisnik godišnje glavne skupštine održane 26. ožujka 1938.
} 
veliki odaziv, ali i zabrinjava što su za izbor novoga odbora postavljene dvije liste. U zapisniku stoji da predsjednik naglašava da „(...) bi upravo sada (...) uoči stogodišnjice, trebalo biti potpuno jedinstvo", no razvidno je da su unutar društva postojale političke tenzije među članovima kojih u tom trenu ima 168.

Društvo je u ožujku 1938. godine pretplaćeno na sljedeće dnevnike, tjednike i časopise: Jutro, Slovenec, Ljubljanski zvon (iz Ljubljane), Oskar, Jutarnji list, Novosti, Hrvatski dnevnik, Hrvatska straža, Narodne novine, Morgenblatt, Istra, Naš glas, Nova riječ, Seljački dom, Narodno kolo, Hrvatska revija, Hrvatski planinar, Priroda, Nova Europa, Svijet, Koprive (iz Zagreba), Politika, Vreme, Srpski književni glasnik (iz Beograda), Novo Doba i Jadranska Straža (iz Splita), Varaždinske novosti i Hrvatsko jedinstvo (iz Varaždina), Neue Freie Presse (iz Beča) i Prager Presse (iz Praga). Na raspolaganju besplatno stoje novine Francuskoga kluba: L'Echo de Belgrade, Beaux-Orts, Le Petit Parisien, Le Monde Illustré, L'Illustration, La Petit Illustration, Les Annales - svega 35 novina i časopisa „što je svakako impozantan broj".95

Te je godine društvo sudjelovalo u „Akciji za pobijanje nepismenosti“ te su u društvenim prostorijama održavani sastanci Akcionog odbora za pobijanje nepismenosti. Kao i prijašnjih godina besplatno su stavili na raspolaganje svoje prostorije raznim društvima za sastanke i skupštine. ${ }^{96}$

Knjižnica u vrijeme održavanja glavne skupštine 1938. godine ima 850 knjiga što znači da su u godinu dana nabavljene 34 nove knjige, a knjižnica je „(...) kupovala gotovo sve značajnije knjige koje su se pojavile na našem književnom tržištu". ${ }^{\prime 7}$

Političke trzavice unutar društva nisu utjecale na odabir predsjednika društva 1938. godine. Na sjednici je 62 glasa dobila lista starog odbora, a 28 glasova lista novog odbora, no obje su liste kandidirale Krešimira Filića za predsjednika. ${ }^{98}$

Filić predlaže da dužnosnici društva 1938. godine budu Edo Filipović (potpredsjednik), Ivan Milčetić (tajnik i knjižničar), Albert Liebermann (blagajnik) i Robert Kronast (gospodar). ${ }^{99}$

\footnotetext{
95 Isto.

96 Isto.

97 Isto.

98 Isto.

99 Rukopisni zapisnik sjednice odbora održane 2. travnja 1938.
} 


\section{PROGRAM PROSLAVE STOGODIŠNJCE NARODNE ČITAONICE}

Za proslavu su društvene stogodišnjice puno ranije poduzete sve potrebne predradnje. Zamolili su sveučilišne profesore iz Zagreba, dr. Ferdu Šišića i dr. Antuna Baraca, da održe svaki po jedno predavanje o ilirskom pokretu na što su se oni odazvali. Upitali su zagrebačko kazalište za nastup, no za to je bilo potrebno ostvariti garantirani prihod od 25.000 dinara za opernu predstavu, a 10.000 za dramsku predstavu. Svjesni činjenice da za željenu opernu predstavu nemaju dovoljno sredstava, traže veću subvenciju od Gradskog poglavarstva i banske uprave u Zagrebu. Saznajemo da je u vezi s proslavom stogodišnjice Filić čak boravio u Zagrebu nekoliko dana, tražio subvenciju od banovine, pregovarao sa zagrebačkom operom te istraživao u arhivima građu za spomenicu. Planiralo se, dakle, da predsjednik Filić za tu prigodu napiše kratku spomenicu i historijat društva, no unatoč već provedenom istraživanju, ona nije tiskana. ${ }^{100}$ Radi bogatog i opširnog programa sama društvena proslava podijeljena je na svibanj 1938. godine, a za završnu svečanost društvene stogodišnjice dalo se tiskati pozivnice. ${ }^{101}$

1.) U subotu, 7. svibnja 1938. godine, u velikoj dvorani varaždinskoga kazališta održan je vokalni koncert Hrvatskog pjevačkog udruženja „Lisinski“ iz Zagreba u kompletnom sastavu od 70 članova i članica pod vodstvom dirigenta profesora Mladena Pozajića. Varaždinska pjevačka društva prisustvovala su dočeku članova Lisinskog i koncertu, a na kraju predstave predali su izvođačima lovorove vijence.

2.) U četvrtak, 11. svibnja 1938. godine, sveučilišni profesor i akademik iz Zagreba, dr. Ferdo Šišić, održao je predavanje u društvenim prostorijama Narodne čitaonice na temu: „Hrvatski ilirizam (njegova politička strana)“ 102

3.) Idući četvrtak, 19. svibnja 1938. godine, sveučilišni profesor iz Zagreba, dr. Antun Barac, govorio je u društvenim prostorijama o temi „Književnici ilirizma u svome vremenu". ${ }^{103}$

4.) Na Spasovo, 26. svibnja 1938. godine, nažalost, zbog previsoke cijene gostovanja (25.000 dinara) i nemogućnosti sniženja troškova puta za 110 gostiju, propao je nastup Zagrebačke opere koja je trebala izvesti operu Krste Odaka „Dorica pleše“. Umjesto opere u velikoj dvorani kazališta koncert je održao Zagrebački komorni orkestar pod vodstvom proslavljenog dirigenta Lovre Matačića. ${ }^{104}$

\footnotetext{
${ }_{100}$ Rukopisni zapisnik sjednice odbora održane 18. ožujka 1938.

${ }^{101}$ Rukopisni zapisnik sjednice odbora održane 28. travnja 1938.

102 Rukopisni zapisnik sjednice odbora održane 2. travnja 1938.

103 Isto.

104 Isto.
} 


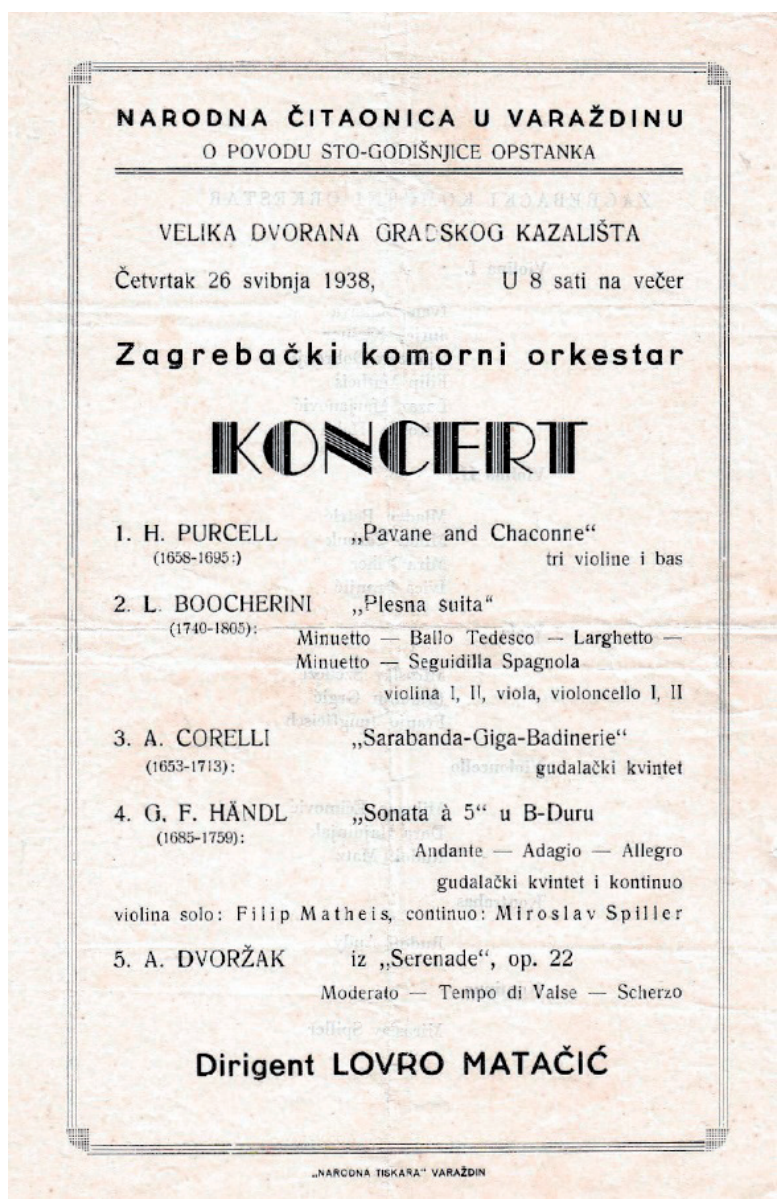

Slika 12. Program koncerta Zagrebačkog komornog orkestra zakazanog za 26. svibnja 1938. ${ }^{105}$

5.) U nedjelju, 29. svibnja 1983. godine, održala se završna svečanost proslave društvene stogodišnjice. U 9 sati ujutro društveni je odbor položio vijence na grobove Tome Blažeka, Ivana Padovca, Vladislava Vežića i Janka Kenfelja. U 10 sati otkrivena je spomen-ploča pjesniku ilircu dr. Stjepanu Ilijaševiću, na kućnom broju 6 u Jagićevoj ulici, a u 11 sati održana je matineja u velikoj dvorani gradskoga kazališta na kojoj je predsjednik održao prigodno spomen-slovo, a pojačani orkestar vojne muzike odsvirao uvertiru „Porin“ Vatroslava Lisinskoga. Pjevački

105 Dokumenti sačuvani u Zavičajnoj zbirci Gradske knjižnice i čitaonice „Metel Ožegović“ Varaždin. 
zborovi „Vile“, „Vijenca“ i „Tomislava“ otpjevali su po jednu pjesmu dok sama matineja završava pjevanjem „Lijepe naše“ koju su izveli udruženi pjevački zborovi. Navečer je u velikoj dvorani gradskoga kazališta održan ples te zajednička večera članova i uzvanika. ${ }^{106}$ Završnu svečanost posjetilo je preko 500 ljudi, „(...) pa je i to dokaz, da čitaonica uživa prijeporan ugled u svim slojevima građanstva i da je vodeća kulturna institucija grada Varaždina“. ${ }^{107}$

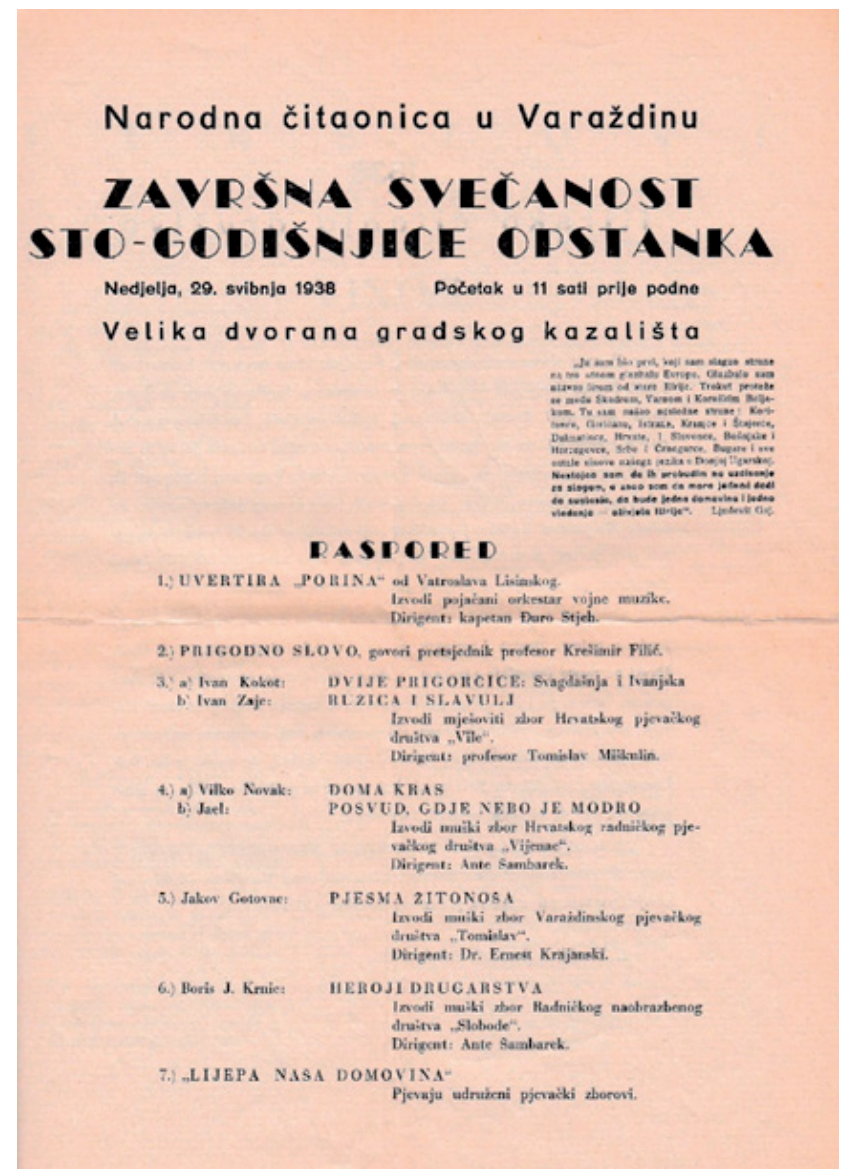

Slika 13. Prva stranica programa tiskanoga prigodom održavanja završne svečanosti 100 -godišnjice Narodne čitaonice. ${ }^{108}$

\footnotetext{
106 Rukopisni zapisnik sjednice odbora održane 16. svibnja 1938.

107 Rukopisni zapisnik godišnje glavne skupštine održane 2. travnja 1939.

108 Dokumenti sačuvani u Zavičajnoj zbirci Gradske knjižnice i čitaonice „Metel Ožegović“ Varaždin.
} 
Kako bi se poboljšali uvjeti prilikom održavanja koncerata, predavanja i zabava, nakon proslave stogodišnjice društva, odlučeno je da se prostorije trebaju preurediti. Bilo je potrebno osvježiti boju zidova te srušiti zid između dvorane za čitanje i srednje dvorane za društvene igre kako bi te dvije prostorije dijelila staklena vrata koja su se prema potrebi mogla sklopiti. Pristupilo se i modernizaciji električne rasvjete koja je bila zastarjela i slaba. ${ }^{109}$ Električni vodovi u objema dvoranama izveli su se u stijenama, u čitaćoj i srednjoj dvorani montirane su tri jake stropne svjetiljke dok su u srednjoj dvorani nad stolovima postavljene najpraktičnije i najekonomičnije svjetiljke za šahiste i kartaše. Nad ulaznim vratima smješteno je alarmno zvono kojim se služilo kod koncerata i predavanja. Obje dvorane oličene su u jednakom svjetlozelenom tonu. ${ }^{110}$

Tijekom zime „Čitaonica“ je priredila četiri koncerta. Uređenje društvenih prostorija poremetio je redoslijed planiranih koncerata u sezoni 1938./1939., no svi su naposljetku izvedeni. Prvi koncert održao je pijanist Eugenij Vanlin, profesor Muzičke akademije u Zagrebu, 5. studenoga 1938. godine. U siječnju je nastupila operna pjevačica Đurđa Halper-Leppée, u veljači gudački kvartet iz Ljubljane, a u ožujku Hrvatsko pjevačko društvo Kolo iz Zagreba. ${ }^{111}$

U ožujku 1939. godine osam je članova Narodne čitaonice podnijelo zahtjev da se društveno ime Narodna čitaonica promijeni u Hrvatska čitaonica. ${ }^{112} \mathrm{U}$ zapisniku odborske sjednice pak piše da „sasvim neovisno od ove akcije, predsjednik predlaže da odbor spontano donese takav zaključak i da ga podnese predstojećoj društvenoj skupštini na prihvat (...). Nijedan od odbornika nema ništa protiv hrvatskog imena, iako ih je većina mišljenja da je „Čitaonica“ i pod starim imenom bila sasvim narodna i hrvatska, pa da se promjenom imena u stvari ništa ne mijenja". ${ }^{113}$

Predsjednik Filić na sljedećoj odborskoj sjednici naglašava da je potrebno ispraviti društvena „Pravila“ te da je osim društvenog imena u pravilima potrebno izmijeniti i neke druge odredbe, a treba ih također jezično i stilistički dotjerati. ${ }^{114}$ Tajnik čita odlomak po odlomak „Pravila“, a odbornici daju svoje prijedloge za promjene. Saznajemo kako unatrag dvije godine nekolicina članova stvara negativnu atmosferu protiv društva i zadnjeg odbora. Društvu se predbacivalo

\footnotetext{
109 Rukopisni zapisnik sjednice odbora održane 19. rujna 1938.

110 Rukopisni zapisnik sjednice odbora održane 12. studenoga 1938.

111 Rukopisni zapisnik sjednice odbora održane 12. siječnja 1939.

112 Rukopisni zapisnik sjednice odbora održane 21. ožujka 1939.

113 Isto.

114 Rukopisni zapisnik sjednice odbora održane 27. ožujka 1939.
} 
kako nije dovoljno „hrvatsko“ što se osudilo kao netočno jer je čitaonica „(...) $90 \%$ pretplaćivala hrvatske novine, časopise i knjige; podupirala - prema financijalnim mogućnostima - svaku hrvatsku kulturnu, prosvjetnu i humanu akciju; sudjelovala je kod svih narodnih manifestacija“. ${ }^{115}$ Prema tome, za predsjednika Filića nije bilo sumnje da se ne može ni sadašnjoj, ni bivšim upravama od 1918. godine predbaciti neka „protunarodna“ djelatnost. Naglašava se kako su prigovori neutemeljeni s obzirom da se društvu prigovara „,(..) što se zove Narodna čitaonica, a to sada prigovaraju pojedini članovi, koji su desetak godina društveni članovi i bili štoviše društveni odbornici, pa ih to ime nije ni najmanje smetalo“. ${ }^{116}$ Ističe se kako nezadovoljni članovi nikad nisu vodili brigu oko financijskog stanja društva, davali korisne prijedloge, predlagali pretplatu za novine, knjige ili časopise. „Svi prigovori bili su općenitog karaktera, a gdjekad zlobni i zlonamjerni. ${ }^{117}$ Prigovore su uputili članovi koji čak po pravilima uopće nisu smjeli biti članovi društva jer su nesamostalne osobe, a nisu ni uredno plaćali članarinu. Usprkos jednoglasnom zaključku odbora da se ime društva promijeni u „Hrvatska čitaonica" odbornici osjećaju da se i dalje nastavlja raditi protiv tadašnjeg odbora te smatraju “(...) da su motivi ove akcije sasvim drugi nego što se prikazuju neupućenim članovima i javnosti. Javna je tajna da neki pojedinci misle da imaju pravo na sav javni rad u Varaždinu, pa se zato žele afirmirati i u Čitaonici ne pitajući kuda bi odveli društvo, da ga kojim slučajem dobiju u ruke. Konačno je poznato, da bi novi ljudi htjeli prepustiti društvene prostorije na uporabu i nekim drugim društvima, a da bi time bio samoj Čitaonici zadan smrtni udarac, ne treba naročito ni spominjati. Čitaonica je bila i treba da ostane samo kulturno-prosvjetna hrvatska ustanova, daleko od dnevne politike. Uvlačenje politike - značilo bi u društvo uvesti nemir, nesklad i razdor i zato takve momente valja bezuvjetno izbjegavati. Odbor zaključuje da se među članovima poradi, da nedjeljna skupština prođe u harmoniji, i da čitaonica zadrži svoj dosadašnji smjer". ${ }^{118}$

$U$ godinu dana od posljednje godišnje skupštine održano je osam sjednica odbora, a broj je članova porastao te sada iznosi 208. Na godišnjoj glavnoj skupštini 1939. godine prisutno je 115 članova te izaslanik Predstojništva gradske policije, agent Marko Karčić. ${ }^{119}$ Pod drugom točkom dnevnoga reda raspravljalo se o promjeni i nadopuni društvenih „Pravila“. U pravilima se tako mijenja prvi

\footnotetext{
115 Isto.

116 Isto.

117 Isto.

118 Isto.

119 Rukopisni zapisnik godišnje glavne skupštine održane 2. travnja 1939.
} 
odlomak gdje sad stoji da se društvo nadalje zove Hrvatska čitaonica. U petom odlomku uvršteno je na zahtjev suca Prohaske da odbor odlučuje o članstvu na prvoj sljedećoj odborskoj sjednici, a još je dodatno tražio zajedno s nekolicinom članova izmjenu osmog odlomka i točke d) nakon čega aktivno i pasivno pravo glasa imaju samo oni članovi koji su najmanje tri mjeseca učlanjeni u društvo. ${ }^{120}$

Nekoliko mjeseci pred početak II. svjetskoga rata društvo je pretplaćeno na čak 40 dnevnika, tjednika, ilustracija i časopisa. Stoga se i ističe da se Hrvatska čitaonica izdvaja iz reda provincijskih čitaonica te se „(...) može staviti uz bok takvim institucijama u drugih većih i kulturnijih naroda“. ${ }^{121}$

Društvo je sudjelovalo na zadušnicama za Zrinskog i Frankopana 30. travnja 1938. godine, poduprlo je akciju za suzbijanje nezaposlenosti, dalo svoj prilog za seljake sela Kolarec koje je zadesio požar, kao i zadruzi za kolonizaciju seljaka, sudjelovalo je i u svečanosti otkrića spomenika dr. Vatroslavu Jagiću pri čemu su položili lovorov vijenac. ${ }^{122}$

Sveukupno je početkom 1939. godine u knjižničnome fondu bilo 899 knjiga što znači da se od prošle skupštine broj knjiga uvećao za $49 .{ }^{123}$ Knjižnica je nabavljala sljedeće edicije: 1 . Maticu hrvatsku (7 knjiga godišnje); 2 . Slovensku maticu (4 knjige godišnje); 3. Srpsku književnu zadrugu (7 knjiga godišnje); 4. Binozu (svjetske pisce, 6 knjiga godišnje); 5. Binozu (domaće i moderne pisce, 6 knjiga); 6. Hrvatsku književnu nakladu neovisnih književnika (6 knjiga); 7. Biblioteku nezavisnih pisaca (Krležina djela, 12 knjiga); 8. Sabrana djela A. G. Matoša (3 knjige). Osim ovih knjiga, nabavljene su i druge knjige ostalih nakladnih poduzeća. ${ }^{124}$

Za izbor odbora podnesene su dvije liste - jedna starog odbora $i$ jedna

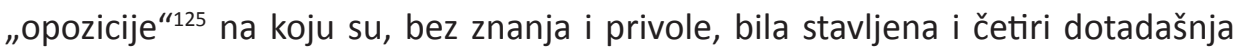
odbornika. Prva lista dobila je 79 glasova, a druga 33 glasa pa tako ponovno imenovani predsjednik Filić „(...) zahvaljuje članovima na velikom odazivu i poziva ih da ubuduće surađuju u društvu u slozi, ljubavi i snošljivosti“. ${ }^{126}$

Dužnosnici Narodne čitaonice 1939. godine su: Edo Filipović - potpredsjednik, tajnik i knjižničar - Ivan Milčetić, gospodar - Rudolf Hršak i blagajnik - Al-

\footnotetext{
120 Isto.

121 Isto.

122 Isto.

123 Isto.

124 Isto.

125 Isto.

126 Isto.
} 
bert Lieberman. Novoizabrani odbor naručuje veliki i moderan ormar za sve veći društveni arhiv. ${ }^{127}$

Prihvaćena društvena pravila predaju se početkom travnja 1939. godine profesoru Paukoviću da ih jezično i stilistički dotjera ako se za to ukaže potreba. Banska uprava vraća potvrđena pravila već u lipnju, a na zahtjev predstojništva gradske policije stavljen je članak o društvenom pečatu i članak o nadzoru prosvjetnih vlasti nad „Čitaonicom“. 128

Na dan 4. lipnja 1939. godine obilježili su proslavu 150-godišnjice francuske revolucije - predsjednik je držao uvodnu riječ, publicist Jutarnjeg lista Josip Horvat održao je predavanje, a gimnazijalci su otpjevali Marseljezu. ${ }^{129}$

Rotary klub u Varaždinu izlazi u susret članovima Hrvatske čitaonice te joj besplatno daje engleske novine The Bulletin and Pictorial i The Glasgow Herald. ${ }^{130}$

Društvo planira tijekom zime 1939./1940. prirediti šest predavanja: dr. Bičanić o ekonomskim i socijalnim prilikama seljaštva u Hrvatskom zagorju, dr. Körhler o raku, ing. Arnold o vrtnoj arhitekturi, prof. Dobrović o slavenskim utjecajima u glazbi, dr. Nenadić o važnosti šuma i prof. Stahuljak o Julijskim alpama. Ujedno se prihvaća i prijedlog da Narodna čitaonica organizira pučko-prosvjetna predavanja po selima. ${ }^{131}$

Na prvoj sjednici odbora poslije početka II. svjetskoga rata tajnik upozorava da uslijed nastalog ratnog stanja društvo treba štedjeti jer postoji bojazan da će doći do poskupljenja, smanjenja broja članova te povećanja izdataka za svjetlo, ogrjev, knjige i novine. Odlučuju da prostorije ostaju otvorene do $22 \mathrm{~h}$, ali da se uvede štednja pri svim ostalim izdatcima. Usprkos ratu i politički motiviranim ispadima pojedinih članova u prostorijama „Čitaonice“, krajem 1939. godine ne obustavlja se kulturni rad (predavanja i koncerti), no politička netrpeljivost među članovima postupno dovodi do sve jačeg razdora u društvu, ali i do ostavke predsjednika društva Krešimira Filića. ${ }^{132}$

Nakon ostavke Krešimira Filića odbornici su suglasni da društvo mora i ubuduće ostati „nezavisna, nepolitička, slobodoumna i napredna hrvatska ustanova koja treba da služi općim kulturnim i prosvjetnim svrhama i ničem drugom “. ${ }^{133}$ Odbor ujedno odlučuje sazvati izvanrednu ili redovnu sjednicu te na njoj oda-

\footnotetext{
127 Rukopisni zapisnik sjednice odbora održane 5. travnja 1939.

128 Rukopisni zapisnik sjednice odbora održane 28. lipnja 1939.

129 Isto.

130 Isto.

131 Isto.

132 Rukopisni zapisnik sjednice odbora održane 11. listopada 1939.

133 Isto.
} 
brati novi odbor, ali tek kada se „smire duhovi i kad će biti moguće sporazumno sastaviti odbor". ${ }^{134}$ No, društvo stagnira u radu, nastupaju mjere štednje te se ne nabavljaju nikakve nove knjige osim onih koje je društvo redovito primalo kao pretplatnik. ${ }^{135}$

\section{GRADSKA PUČKA KNJIŽNICA}

Nakon završetka I. svjetskoga rata u Varaždinu su postojale jedino knjižnice zatvorenog tipa u sklopu samostana, škola, raznih društava i čitaonica. Štoviše, u cijeloj se državi javlja potreba za utemeljenjem javnih, pučkih knjižnica s ciljem prosvjetnog i kulturnog djelovanja na šire slojeve društva i pučanstva. Taj su prosvjetno-kulturni pokret za osnivanje pučkih knjižnica u selima i gradovima pokrenuli zagrebački srednjoškolci i studenti na početku 20. stoljeća (1902. godine). No, pokušaj da se takva ustanova osnuje u Varaždinu na samom početku 20. stoljeća propada zbog inertnosti gradskih vlasti i njihova nedovoljna razumijevanja i povjerenja u inicijativu mladih. ${ }^{136}$

Prije utemeljenja Gradske pučke knjižnice značajnije knjižnice zatvorenoga tipa u Varaždinu bile su franjevačka, kapucinska, uršulinska, knjižnica Narodne čitaonice te dvije njemačke knjižnice (Platzerova i oficirska). ${ }^{137}$ Budući da knjižnice zatvorenoga tipa nisu omogućavale prosvjećivanje širih slojeva naroda, krajem 1918. godine povela se inicijativa da se za ostalo građanstvo i školarce u gradu osnuje knjižnica kako bi i oni imali pristup novinama, časopisima i knjigama. Povoljni uvjeti za utemeljenje Gradske pučke knjižnice nastupaju ubrzo poslije završetka Prvoga svjetskoga rata kad upravo studenti preko javnih glasila mole građanstvo i varaždinska društva za financijska sredstva, knjige i časopise kako bi se buduća pučka knjižnica mogla opremiti. S obzirom da je Jugoslavensko akademsko društvo „Tomislav“ pokrenulo i poduprlo inicijativu varaždinske omladine te bilo najzaslužnije za osnivanje varaždinske Gradske pučke knjižnice, kojoj su nakon gašenja „Tomislava“ bila dodijeljena sva financijska sredstva od likvidacije toga društva kao i sva preostala knjižna imovina, smatramo da je u nastavku, barem u najužim crtama, nužno pružiti osnovne informacije o djelovanju toga društva te njihove knjižnice.

\footnotetext{
134 Isto.

135 Rukopisni zapisnik sjednice odbora održane 6. prosinca 1939.

136 Drago Bišćan, „Gradska pučka knjižnica 1919.-1947.“, Godišnjak Gradske knjižnice i čitaonice „Metel Ožegović" Varaždin, broj 1, gl. ur. Marijan Kraš, Varaždin, 1995., 39. - 40.

137 Isto, 39.
} 


\section{JUGOSLAVENSKO AKADEMSKO DRUŠTVO „TOMISLAV“}

Akademsko društvo „Tomislav“ osnovali su mladi akademičari iz Varaždina 1905. godine, a cilj mu je bila prosvjeta puka i promicanje kulture među širim slojevima društva. Pučko-prosvjetnu djelatnost vršili su organiziranjem glazbenih i dramskih priredbi, javnih jednosatnih predavanja u gradskom kazalištu i okolnim selima. ${ }^{138}$ Najagilniji su bili na području suzbijanja nepismenosti i organizacije predavanja o poboljšanju higijenskih i ekonomskih prilika koja su držali liječnici, svećenici, književnici, studenti te srednjoškolski i sveučilišni profesori. ${ }^{139}$ Nakon rata članovi društva organizirali su večernju trgovačku školu, tečajeve stranih jezika, izdavali brošure o pučkim predavanjima te mjesečnik za promicanje pučko-prosvjetne djelatnosti Naše doba koji je, nažalost, prestao izlaziti već 1920. godine iz financijskih razloga. ${ }^{140}$

Od 1918. do 1921. godine u varaždinskoj okolici „Tomislav“ je organizirao čak 59 predavanja čija je svrha bila potaknuti seosko stanovništvo na organizaciju tečajeva za nepismene. Tečajeve za nepismene „Tomislav“ je organizirao i u Varaždinu, prvenstveno za vojnike i radništvo, a podučavali su ih srednjoškolci. Po selima su analfabetske tečajeve držali pismeni mještani. ${ }^{141}$

Nakon završetka I. svjetskoga rata društvo nosi ime Jugoslavensko akademsko društvo „Tomislav“, a od posebnoga značaja za međuratnu knjižničnu djelatnost bilo je jer je zbog širokog spektra svojih prosvjetiteljskih aktivnosti imalo knjižnicu. Ona je bila zatvorenoga tipa pa su jedino aktivni članovi i seniori mogli posuđivati knjige iz nje, a uvjet je bio i da stalno borave u Varaždinu. ${ }^{142}$ Svi članovi koji su željeli posuditi knjigu morali su se javiti knjižničaru kako bi ih on unio $u$ popis posuđivača dok su samo oni članovi koji su platili članarinu mogli posuđivati knjige. ${ }^{143}$

Knjižničara je odabirao odbor. On je bio zadužen kontrolirati da se svi pridržavaju propisa, voditi katalog knjižnice, popis posuđivača te „Knjigu globa“ u koju su se bilježili iznosi naplaćenih kazni ako se knjige nisu vratile na vrijeme. ${ }^{144}$ Katalog knjižnice Jugoslavenskog akademskog društva „Tomislav“ bio je organizi-

\footnotetext{
138 Siniša Horvat, „Historijat Varaždinske gimnazijske ekstenze“, Hrvatska akademija znanosti i umjetnosti, Radovi Zavoda za znanstveni rad Varaždin, 14-15/2004, 76.

139 Isto, 76.

140 Isto, 76.

141 Rudolf Maixner, „Akademsko društvo Tomislav u Varaždinu“, Zbornik za pučku prosvjetu, Svezak 1-2, Pučko sveučilište u Zagrebu, Zagreb,1992.

142 Pravilnik društvene knjižnice Jugoslavenskog akademskog društva „Tomislav“.

143 Isto.

144 Isto.
} 
ran prema „(...) strukama u 11 razreda“. ${ }^{145}$ Te razrede sačinjavali su: 1 . Časopisi; 2. Romani, novele i crtice; 3. Epika, lirika i dramatika; 4. Memoari, književni eseji, biografije i kritike; 5 . Historija, pravo i politika; 6. Geografija, putopisi i statistika; 7. Prirodne nauke; 8. Gospodarstvo; 9. Filozofija, pedagogija, teologija, socijalne znanosti; 10. Zemljovidi; 11 . Različito. ${ }^{146}$

Svaka knjiga imala je signaturu s društvenim žigom, a signatura se sastojala od rimskoga broja, koji je označavao razred, i arapskoga broja, koji je označavao redni broj. Članovi su morali paziti da knjigu ne oštete, a ako bi ju netko izgubio, morao je nabaviti istu takvu ili platiti iznos trenutne tržišne cijene za tu knjigu. Zabranjeno je bilo da članovi posuđuju knjige drugima jer su u tom slučaju zauvijek izgubili pravo posuđivanja knjiga. Zabavna se literatura posuđivala na dva tjedna dok su se znanstvene knjige posuđivale na period od četiriju tjedana. Članovi koji su željeli posuditi knjigu morali su je potražiti u katalogu i ispuniti formular. Knjige su se mogle posuđivati i vraćati samo u određene dane i u unaprijed naznačeno vrijeme. Dva tjedna prije održavanja glavne godišnje skupštine knjižničar je bio dužan prikupiti sve knjige i obustaviti njihovo posuđivanje kako bi se provela inventura i skupštini podnijelo izvješće o radu i poslovanju knjižnice. Novi knjižničar morao je u prisutnosti prijašnjega usporediti stvarno stanje knjiga u ormaru s katalogom nakon čega se sastavljao zapisnik. Ako bi se kasnije utvrdile neke nepravilnosti koje nisu bile navedene u zapisniku, odgovornost je snosio knjižničar. U slučaju da knjižničar nije znao navesti počinitelja, bio je dužan sam podmiriti štetu. Odbor je svake godine donosio odluke o nadopunjavanju inventara knjižnice i odredio koja će se dijela nabaviti dok su članovi mogli pismenim putem odboru prenijeti svoje čitalačke želje.

Jugoslavensko akademsko društvo „Tomislav“ oformilo je i putujuće knjižnice kako bi pisana riječ bila dostupna i žiteljima okolnih mjesta. Rad putujuće knjižnice bio je reguliran Pravilnikom za putujuće knjižnice Jugoslavenskog akademskog društva „Tomislav“ u Varaždinu. Putujuće knjižnice mogle su se posuđivati samo za područje Varaždinske županije i Međimurja, a njihova namjera bila je prosvjećivanje seoskoga naroda. Rad putujućih knjižnica organizirao je knjižničar prema „Pravilniku“ te je ujedno bio odgovoran za eventualnu nastalu materijalnu štetu. Knjižničar je vodio „Katalog knjižnice“ i statistiku u koju je upisivao podatke o poslovanju povjerenika s putujućom knjižnicom. ${ }^{147}$

\footnotetext{
145 Isto.

146 Isto.

147 Pravilnik za putujuće knjižnice Jugoslavenskog akademskog društva „Tomislav“.
} 
Dakle, putujuća se knjižnica sastojala od ormarića s knjigama koje je knjižničar izdavao društvenim povjerenicima koji su s putujućom knjižnicom bili dužni postupati prema „Pravilniku“. Već ujesen 1919. godine bile su osnovane dvije putujuće knjižnice, a za svaku od njih nabavilo se oko 160 djela koja su bila smještena u ormarićima. Odmah na početku jedna je krajem rujna krenula u Bartolovec, a druga u Zamlaču. ${ }^{148}$ Povjerenici tj. seoski knjižničari su većinom bili seljaci, a putujuće su knjižnice bile veliki uspjeh i omiljene među mještanima sela. ${ }^{149}$ Knjižničari su knjige posuđivali čitačima koji su ih bili dužni čuvati i vraćati na vrijeme. U slučaju gubitka knjige, posuđivač knjige bio je dužan nadomjestiti je istom ili platiti kaznu u iznosu trenutne cijene knjige na tržištu. Isto je tako bilo zabranjeno posuđene knjige davati trećim osobama. Ako bi došlo do oštećenja za koja povjerenik nije znao počinitelja, štetu je bio dužan nadomjestiti sam. Kod preuzimanja ormarića povjerenik je morao utvrditi odgovara li broj i vrsta knjiga onima na popisu te je do predaje knjižničaru odgovarao za svaku štetu. Ormarić s knjigama bilo je dozvoljeno u jednom mjestu zadržati najdulje tri mjeseca dok se posuditi smjela samo jedna knjiga na dva tjedna. Posuđivanje ormarića s knjigama bilo je besplatno, no posuđivač je bio dužan snositi troškove otpreme i dopreme ormarića. U ormariću se nalazio jedan primjerak Pravilnika za putujuće knjižnice Jugoslavenskog akademskog društva „Tomislav“, katalog s popisom knjiga i arak za statistiku u koji je povjerenik bilježio svoje knjižnično poslovanje. ${ }^{150}$ Odbor je mogao i imenovati revizora da pregleda poslovanje knjižnice. Dva tjedna prije održavanja godišnje glavne skupštine sve putujuće knjižnice morale su biti vraćene u društvene prostorije kako bi se izvršila revizija i sastavilo izvješće koje je revizor podnosio skupštini. Izvješće o poslovanju putujućih knjižnica skupštini je podnosio i knjižničar koji je bio odgovoran za svako oštećenje i gubitak knjiga. ${ }^{151}$

\footnotetext{
148 Rudolf Maixner, „Akademsko društvo Tomislav u Varaždinu“, Zbornik za pučku prosvjetu, Svezak 1-2, Pučko sveučilište u Zagrebu, Zagreb, 1992.

149 Isto.

150 Pravilnik za putujuće knjižnice Jugoslavenskog akademskog društva „Tomislav“.

151 Isto.
} 

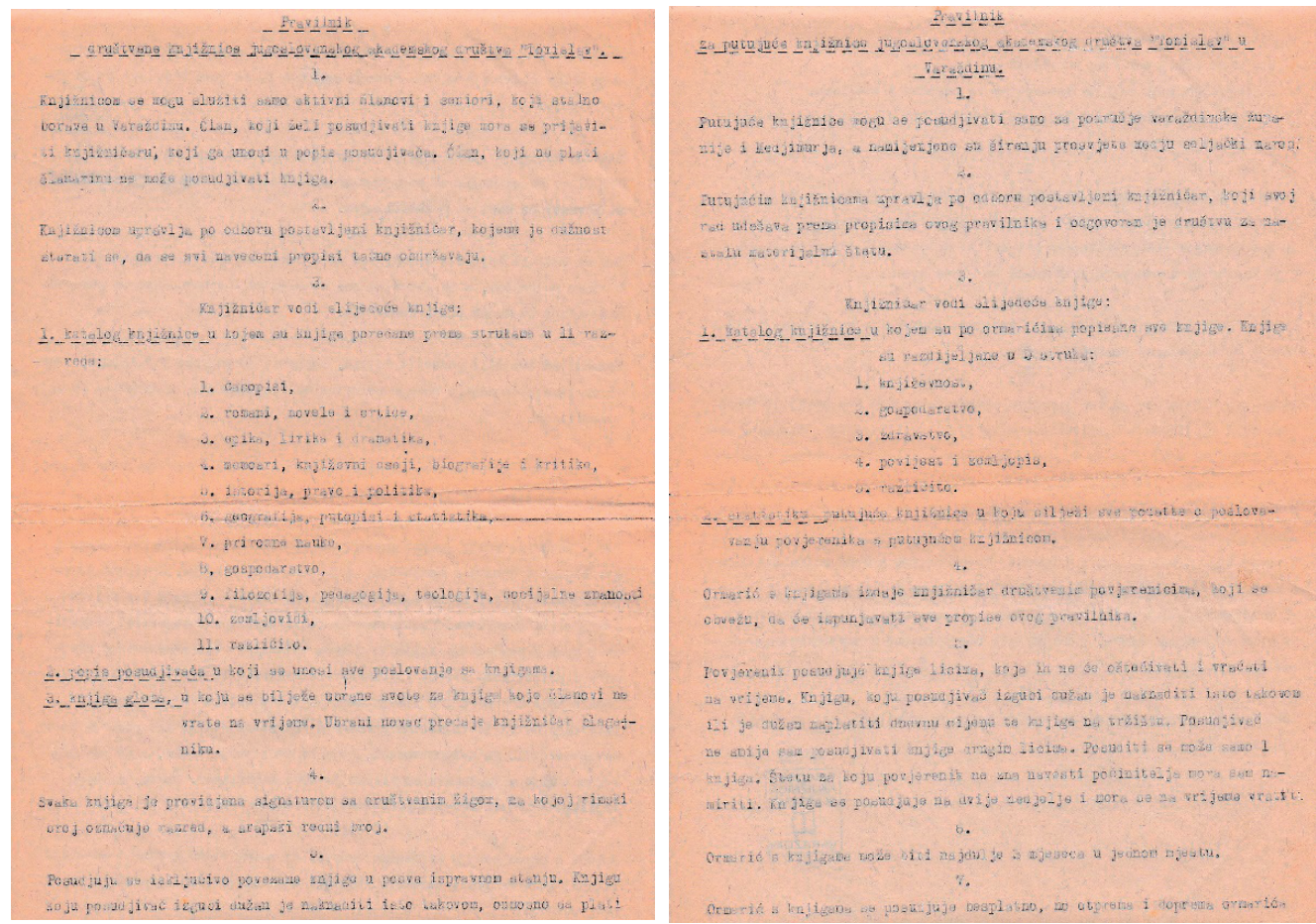

Slika 14. Početne stranice Pravilnika društvene i Pravilnika putujuće knjižnice Jugoslavenskog akademskog društva „Tomislav“. ${ }^{152}$

lako su „tomislavaši“ nakon završetka I. svjetskoga rata entuzijastično i energično radili na prosvjećivanju i kulturnoj aktivnosti svih slojeva društva, 1922. godine dolazi do stagnacije njihovih aktivnosti što traje sve do gašenja društva 1927. godine. Nakon likvidacije Tomislava, novac od prodaje inventara predan je upravo Gradskoj pučkoj knjižnici zajedno s preostalih 127 knjiga te nekoliko brošura i časopisa. ${ }^{153}$

\footnotetext{
152 Dokumenti sačuvani u Zavičajnoj zbirci Gradske knjižnice i čitaonice „Metel Ožegović“ Varaždin.

153 Drago Bišćan, „Gradska pučka knjižnica 1919.-1947.“, 41. - 43.
} 

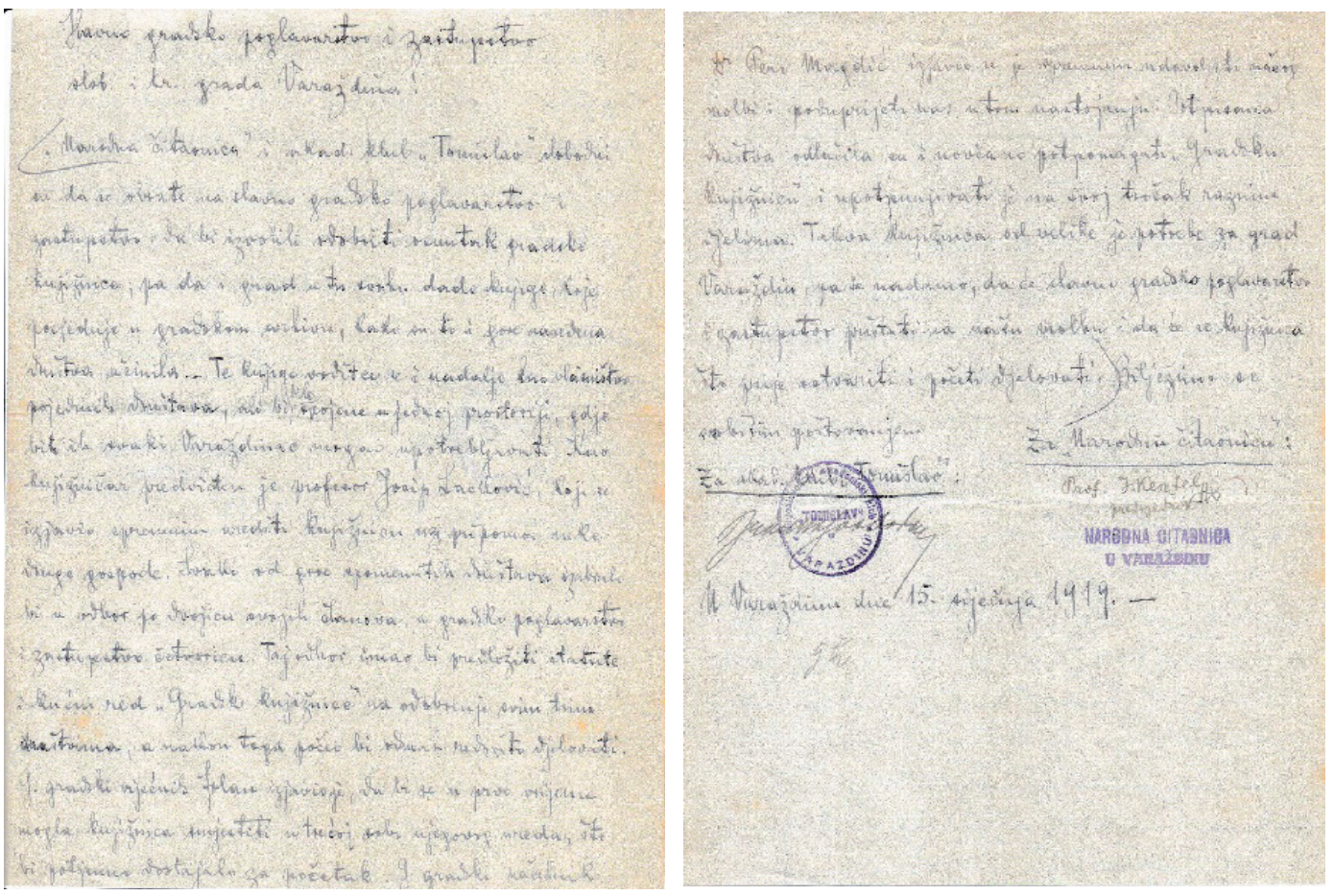

Slika 15. Rukopisni dopis kojim Jugoslavensko akademsko društvo „Tomislav“ i Narodna čitaonica iniciraju osnivanje Gradske pučke knjižnice. ${ }^{154}$

Kao što je već prije spomenuto, ključnu ulogu kod osnivanja Gradske pučke knjižnice u Varaždinu imalo je upravo Jugoslavensko akademsko društvo „Tomislav" s obzirom da je zajedno s Narodnom čitaonicom uputilo dopis 15. siječnja 1919. godine Gradskom poglavarstvu i zastupstvu slobodnoga i kraljevskoga grada Varaždina tražeći ne samo dozvolu za osnutak pučke knjižnice nego i donaciju knjiga iz gradskoga arhiva. U tom istom rukopisnom dopisu oba su se društva obvezala donirati svoje knjige, ali i pružiti određenu financijsku potporu Gradskoj pučkoj knjižnici. Gradsko poglavarstvo udovoljilo je njihovom pisanom zahtjevu, a potvrdu o pruženoj pomoći pri osnivanju javne gradske knjižnice nalazimo u rukopisnim zapisnicima sa sjednica odbora Narodne čitaonice kad u siječnju 1919. godine tadašnji odbornik Filić predlaže da se sve knjige u inventaru čitaoničke knjižnice ustupe Gradskoj pučkoj knjižnici. Nakon što su knjige Narodne čitaonice popisane, upravni je odbor predao čitavu knjižnicu (1009 knjiga) i tri ormara na

${ }^{154}$ Dokumenti sačuvani u Zavičajnoj zbirci Gradske knjižnice i čitaonice „Metel Ožegović“ Varaždin. 
uporabu Gradskoj pučkoj knjižnici kao i sve uvezane časopise Narodne čitaonice koji nisu bili u „subabonementu“. ${ }^{155}$ Dakle, na samom početku rada Gradsku pučku knjižnicu podupirali su novčano i nabavom djela o svom trošku Narodna čitaonica, Jugoslavensko akademsko društvo „Tomislav“ i Gradsko poglavarstvo. Donirane su knjige i dalje ostale u vlasništvu društava i grada, samo su bile smještene na jednome mjestu te dostupne svakom Varaždincu.

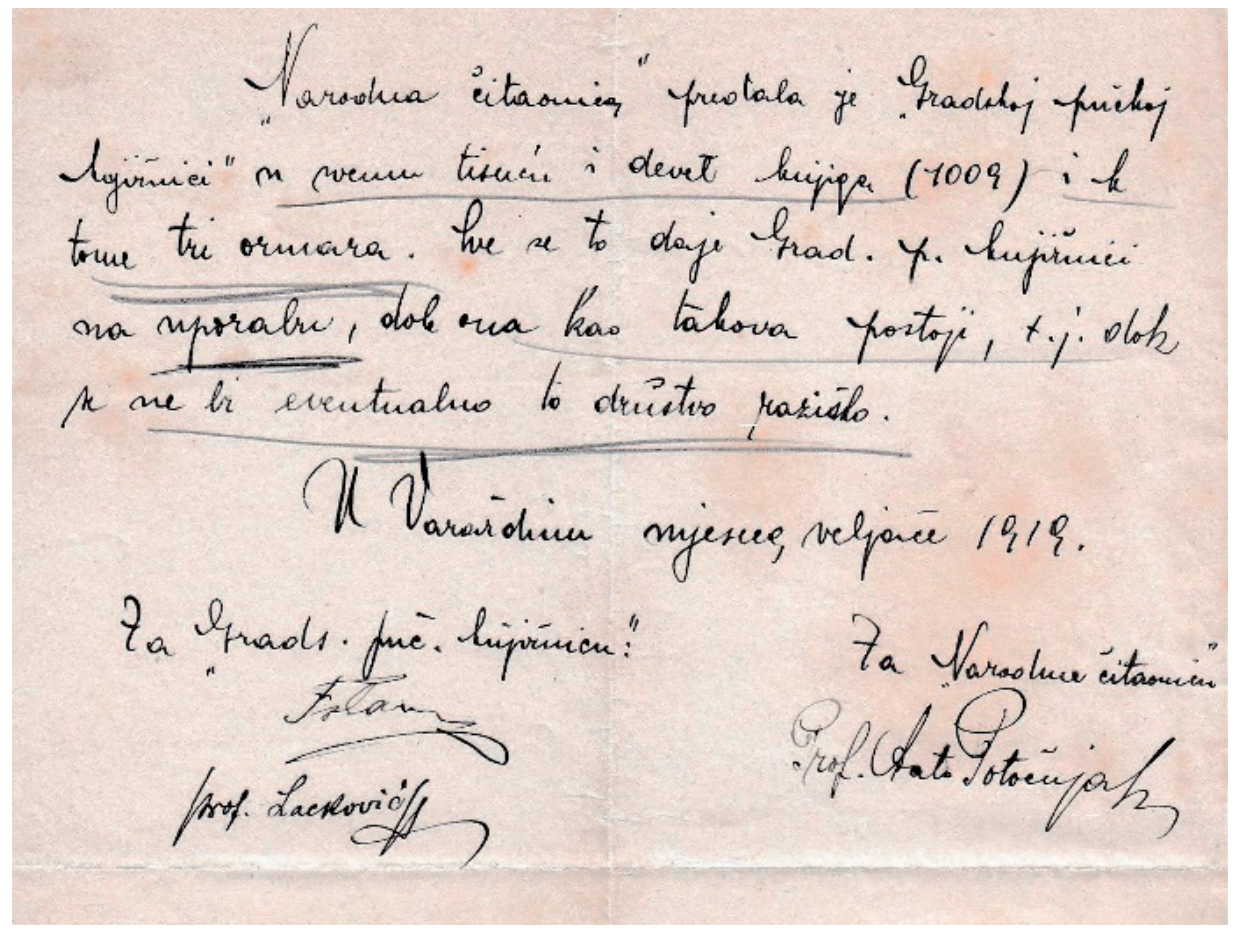

Slika 16. Potvrda o donaciji 1009 knjiga i tri ormara

Narodne čitaonice Gradskoj pučnkoj knjižnici. ${ }^{156}$

Gradskom pučkom knjižnicom upravljao je upravni odbor koji je činilo osam članova: četvero iz Gradskoga poglavarstva te po dvoje iz Narodne čitaonice i Jugoslavenskog akademskog društva „Tomislav“. ${ }^{157}$ Prvobitna zadaća odbora bila

155 U rukopisne zapisnike Narodne čitaonice unesena je napomena da se, u slučaju zatvaranja Gradske pučke knjižnice, ustupljene knjige moraju vratiti „Čitaonici“.

156 Dokumenti sačuvani u Zavičajnoj zbirci Gradske knjižnice i čitaonice „Metel Ožegović“ Varaždin.

157 U rukopisnim zapisnicima sa sjednica odbora Narodne čitaonice Gradsko poglavarstvo traži po prvi put na samom početku 1919. godine da se dva člana odaberu u nadzorni odbor Gradske pučke knjiž- 
je sastaviti statut i kućni red, a nakon njihova odobrenja od strane svih triju strana, knjižnica je mogla početi s radom. Dužnost prvoga knjižničara Gradske pučke knjižnice prihvatio je profesor Josip Lacković dok je gradski vijećnik Mato Frlan ponudio da se čitaonica za početak smjesti u trećoj sobi njegova ureda. Čak je i gradski načelnik dr. Pero Magdić podupirao inicijativu za formiranje Gradske pučke čitaonice.

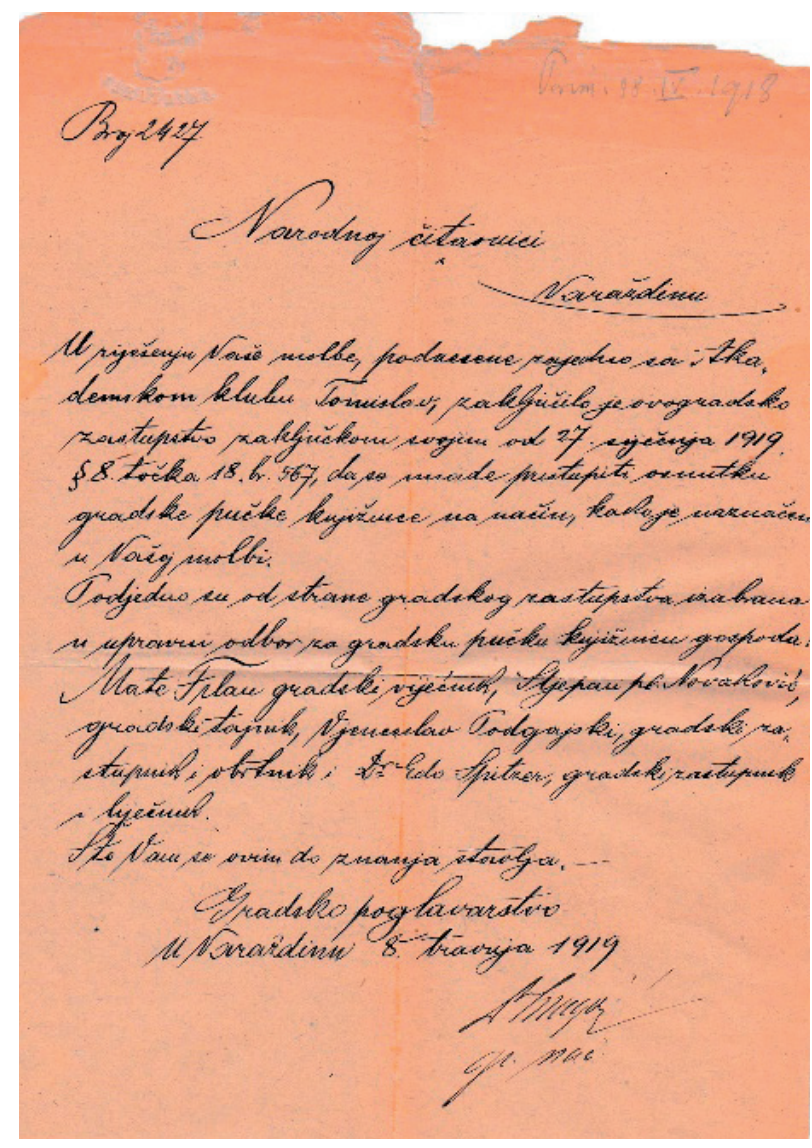

Slika 17. Dopis kojim Gradsko poglavarstvo obavještava Narodnu čitaonicu da je 27. siječnja 1919. g. odobreno osnivanje Gradske pučke knjižnice. ${ }^{158}$

nice, a odabrani su bili tadašnji knjižničar Spiller i tajnik Potočnjak. Tako je svake godine Narodna čitaonica na sjednici odbora birala dva člana, od kojih je jedan bio knjižničar, u odbor Gradske pučke knjižnice. Knjižničar Narodne čitaonice bio je ujedno i zadužen voditi brigu o društvenim knjigama u Gradskoj pučkoj knjižnici i izvijestiti društvo o stanju tih knjiga.

158 Dokumenti sačuvani u Zavičajnoj zbirci Gradske knjižnice i čitaonice „Metel Ožegović“ Varaždin. 
Knjižnica je svečano otvorena u nedjelju, 2. ožujka 1919. godine, a predsjednik Upravnoga odbora, Mato Frlan, održao je govor pred mnogobrojnim Varaždincima. Općenito su javne knjižnice u tadašnje doba otežano radile zbog siromaštva i vlasti koja nije izdvajala dovoljno sredstava uslijed nepostojanja zakona o knjižnicama koji bi uredio njihovo poslovanje te osigurao sredstva i profesionalni kadar. ${ }^{159}$ Gradska pučka knjižnica funkcionirala je upravo zahvaljujući donacijama knjiga i financijskih sredstava raznih društava, gradske uprave, istaknutih Varaždinaca i dr. Knjige je Gradska pučka knjižnica također dobivala zahvaljujući donacijama varaždinskih građana što se obično objavljivalo u domaćim glasilima. Poznato je da je rad započela s 3.100 poklonjenih knjiga, a 1922. godine imala je već preko 5.000 svezaka. ${ }^{160}$

Nakon nekoliko godina rada najvećim problemom pokazalo se to što su u knjižnici radili i knjige izdavali volonteri koji nisu imali iskustva ni profesionalne obuke u knjižničnom radu. Dodatna otežavajuća okolnost bila je ta da su se knjige posuđivale dva puta na tjedan u trajanju od jednog sata. Zbog velikog priljeva čitača koji su vraćali knjige i onih koji su ih željeli posuditi dolazilo je do gužve u jednoj prostoriji gdje su se knjige držale, vraćale i izdavale što je imalo za posljedicu da su mnoge knjige nestale ili bile oštećene. Nakon provedene akcije sređivanja knjižnice 1925. godine, ustanovljeno je da je nestalo oko 1.000 knjiga te je broj knjiga pao na 4.000. ${ }^{161}$ Tada su napravljeni novi katalozi te je izvršena podjela knjižne imovine po strukama. Knjižnica je obuhvaćala beletristiku, znanstvena djela te publicistiku. ${ }^{162}$ Posebna pažnja posvećena je srednjoškolcima za koje je osnovan zaseban odjel s knjigama domaćih pisaca čija djela su se morala pročitati za lektiru. Za posuđivanje tih knjiga školarci su plaćali deset dinara godišnje, a ta sredstva utrošena su za nabavu knjiga koje su bile na popisu lektire. ${ }^{163}$ Gradska pučka knjižnica u međuratnom razdoblju nikad nije imala više od 500 čitatelja, polovica kojih su bili upravo đaci. ${ }^{164}$

Podatci o Gradskoj pučkoj knjižnici iz očuvane primarne literature vrlo su šturi. Od izvornih dokumenata Gradske pučke knjižnice ostalo je svega nekoliko

\footnotetext{
159 Drago Bišćan, „Gradska pučka knjižnica 1919.-1947.“, 44.

160 Isto, 44.

161 Do nestanka tako znatnoga broja djela došlo je uslijed nepostojanja knjižničara, skučenosti prostora i velikog protoka čitača u kratkom radnom vremenu Gradske pučke knjižnice. Rukopisni zapisnik sjednice odbora Narodne čitaonice održane 18. siječnja 1926. godine potvrđuje da je odbor, zbog „(...) katastrofe, koja je snašla Gradsku knjižnicu (...)“, konstatirao da su i mnoge knjige Narodne čitaonice nestale, a njihov je knjižničar tada dobio zadatak da istraži točno koliko i koje su društvene knjige nestale, a tražio se i povratak onih knjiga Narodne čitaonice koje se nisu posuđivale.

162 Drago Bišćan, „Gradska pučka knjižnica 1919.-1947.“, 45.

163 Isto, 46.

164 Isto, 47.
} 
„Računskih knjiga“, „Dnevnik posudioca knjiga“ te razni katalozi. U najopsežnijem, rukom pisanom katalogu prvo je navedeno ime pisca, zatim naslov djela, mjesto, broj primjeraka, broj svezaka, vrijednost, stanje knjige te godina njene nabave. ${ }^{165} \mathrm{U}$ tom katalogu postojao je i stupac za opaske gdje eventualno stoje podatci o tome tko je određene knjige darovao, stanje knjiga, napomene o neizdavanju ili gubitku knjiga, njihovoj dotrajalosti, krađi ili gubitku, a nešto kasnije navode se i izdavači. Zatim, postojao je „Katalog knjiga po djelima“ u kojem se prvo navodi naslov djela pa pisac te „Katalog knjiga po piscima“ gdje je prvo naveden pisac nakon čega slijedi naslov djela i knjižničarska oznaka. Ostali katalozi predstavljaju već spomenuti svojevrsni pokušaj podjele knjižnog inventara. Knjige Gradske pučke čitaonice su popisane još u „Katalogu đačkih knjiga“, „Katalogu djela za djecu i gimnazijsku mladež nižih razreda“, „Katalogu djela za djecu i gimnazijsku mladež do 4. razreda“, „Katalogu djela za djecu i gimnazijsku mladež do 5. razreda“ te u katalozima nazvanima „Historija, geografija, politika i socijalne znanosti“ i „Beletristika, religija, filozofija, literarna historija i filologija“. Postojala je i „Knjiga reversa“ za knjige Hrvatske knjižnice gdje se unosio dan primitka, broj knjige, potpis primatelja i potpis davatelja, a od sredine knjige broj, pisac, naslov, izdanje, cijena i eventualno neka opaska.

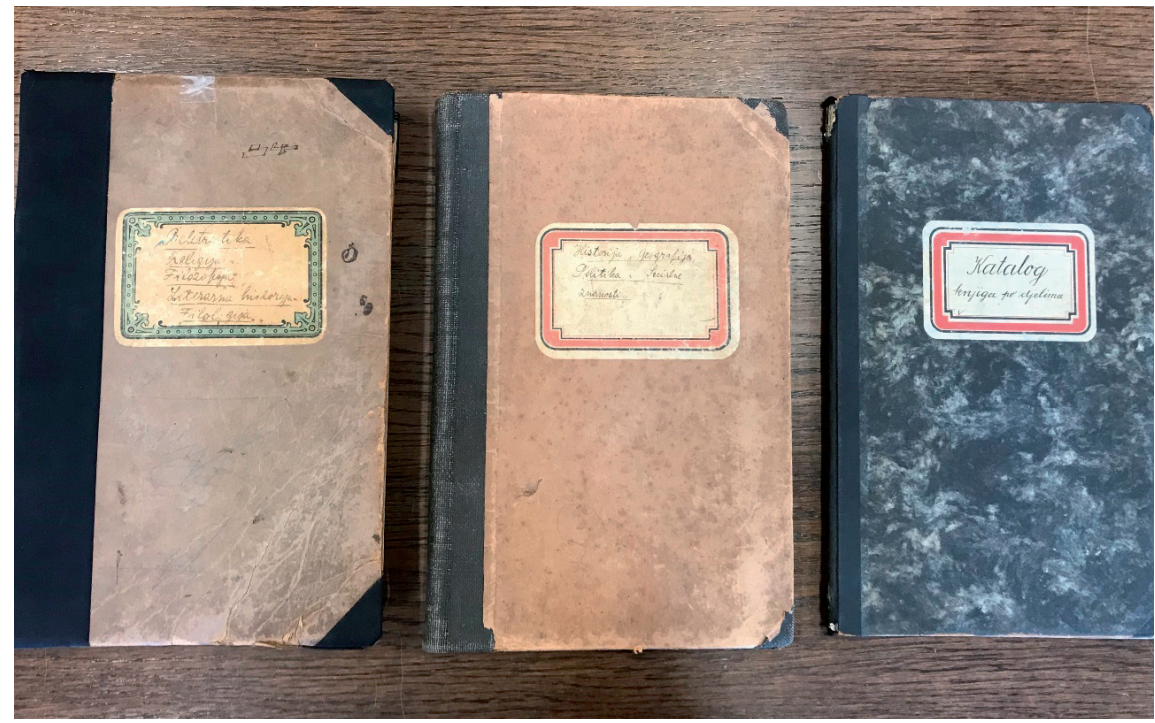

Slika 18. Neki od sačuvanih rukopisnih kataloga Gradske pučke knjižnice. ${ }^{166}$

165 Godina se nabave bilježi tek od sredine kataloga, tj. od 1932. godine.

166 Dokumenti sačuvani u Zavičajnoj zbirci Gradske knjižnice i čitaonice "Metel Ožegović“ Varaždin. 
„Računska knjiga“ Gradske pučke knjižnice pruža nam detaljniji uvid u informacije o prihodima i rashodima knjižnice. Prihode je ostvarivala upisninama, uplatama đačke članarine, dotacijom Gradskog poglavarstva u iznosu od 5.000 dinara godišnje, doprinosima čitača i globama dok pod stavkama rashoda stoji uvez knjiga, nabavka knjiga od izdavačkih kuća, zatim beletrističkih listova pa olovaka, listića, računa iz Hartmanove knjižare, iz Stiflerove tiskare i sl. Zanimljiv je i podatak da je 1933. godine plaćen izvršeni prijenos knjiga iz kuće prof. Krešimira Filića što znači da im je donirao pozamašan broj knjiga.

Pred sam početak II. svjetskoga rata Gradska pučka knjižnica naručuje npr. ilustrirani tjednik Obitelj, djela Zabavne biblioteke, Matice hrvatske, Savremene biblioteke, Binoze (domaće i svjetske pisce), izdanja Minerve i sl., a nabavlja i pisaći stroj. Nažalost, najvjerojatnije s objavom ratnoga stanja u Varaždinu dolazi i do obustave rada Gradske pučke knjižnice.

\section{KNJIŽNICA RADNIČKOG PROSVJETNO-KULTURNOG DRUŠTVA „SLOBODA“}

Društvo osnovano sredinom prvog desetljeća dvadesetoga stoljeća i prvobitnoga imena Radničko naobrazbeno društvo "Sloboda“ imalo je veliku ulogu u okupljanju radnika, njihovu odgoju te širenju naprednih svjetonazora kao i u podizanju njihove klasne svijesti i želje da se uključe u kulturni život Varaždina. Obrazovne i kulturno-umjetničke djelatnosti Slobode obuhvaćale su rad pjevačkog i tamburaškog zbora, diletantske dramske skupine, priređivanje raznih obrazovnih tečaja, tečaja esperanta, predavanja s temama bitnima za radništvo, zabavu i izlete, a kasnije i rad radničke knjižnice. Ovakav širok spektar aktivnosti bio je nužan kako bi se obuhvatilo što više interesnih područja radnika najrazličitijih struka.

Pred sam kraj I. svjetskog rata varaždinski radnici priželjkuju revitalizaciju "Slobode“ unutar koje bi mogli nastaviti njegovati svoje kulturno-umjetničke vrijednosti te se općenito kulturno ostvarivati. Društvu je odobreno da povodom obilježavanja blagdana Svih svetih već 1917 . godine na varaždinskome groblju otpjeva tužaljku u čast poginulih radnika pa okupljanje „Slobodinog“ pjevačkoga zbora počinje bez dobivene dozvole lokalnih vlasti. ${ }^{167}$ Upravo ih je taj događaj potaknuo na ponovno, u tom trenu još uvijek ilegalno, okupljanje nakon čega počinju s pripremom prvomajske proslave za 1918. godinu i organizacijom radničkih zabava s ciljem skupljanja sredstava za obitelji svojih poginulih kolega. ${ }^{168}$

\footnotetext{
167 Spomenspis Radničkog kulturno-prosvjetnog društva "Sloboda“ 1905.-1935., glavni i odgovorni urednik Pongračić Stjepan, Tisak „Svobodine narodne tiskare“, Varaždin, 1935., str. 13.

168 Isto, str. 40.
} 
Prvu poslijeratnu sjednicu, kojoj prisustvuje svega 40 članova, saziva Čagran 1. listopada 1918. godine. Za ostvarenje raznih obrazovnih i kulturno-umjetničkih aktivnosti radnika bilo je ključno da se odmah poslije završetka rata okupe članovi prijeratne "Slobode“ i obnove rad, povećaju broj članova te ponovno osnuju pododbore za pjevački i tamburaški zbor, diletantsku grupu, plesnu školu i predavanja s temama bitnima za radništvo. ${ }^{169}$ Budući da je većina dokumentacije nestala u dvama svjetskim ratovima, informacije o ovom društvu vrlo su šture, pogotovo one o radu knjižnice koja je djelovala unutar „Slobode“. O početku rada knjižnice „Slobode“ nema točnih informacija. U samim početcima knjige su se nabavljale zamolbama u novinama i apelom upućenim članovima i simpatizerima da društvu poklone knjige. Osnivanjem knjižnice u sklopu društva željelo se prvenstveno podići svijest radničke klase koja je i sama izlaz iz svojeg bijednog stanja vidjela u kulturno-obrazovnim aktivnostima.

Budući da se društvo još prije rata okrenulo socijaldemokratima u nadi da će se izboriti za njihov bolji položaj te kulturno-prosvjetnu izgradnju, režim ih je budno nadzirao i kontrolirao pa je za svako njihovo okupljanje trebala dozvola vlasti. ${ }^{170}$ Samo su društvo u još naprednijem djelovanju dodatno kočile osobne političke i građanske ambicije pojedinih članova na rukovodećim položajima u društvu zbog čega na redovnim glavnim godišnjim skupštinama učestalo dolazi do smjene predsjednika, voditelja pododbora društva te ostalog rukovodećeg kadra. Zbog širenja marksističke ideologije i činjenice da je među članovima bilo istaknutih ljevičara društvo je u nekoliko navrata bilo raspušteno i zabranjeno. ${ }^{171}$ Vlasti zabranjuju rad „Slobode“ čak u dva navrata u razdoblju od 1919. do 1921. godine, a za radništvo je svako gašenje „Slobode“ značilo nazadovanje u svakom društvenom i kulturnom pogledu. ${ }^{172}$

Povoljan trenutak za ponovnu reaktivaciju društva dogodio se 1923. godine kad je Varaždin posjetio kraljevski namjesnik za Hrvatsku i Slavoniju kojega su tom prilikom „Slobodaši“ zamolili za dozvolu da obnove rad društva uz obećanje da će izbjegavati svako političko djelovanje. Nastavak rada "Slobode“ bio je nužan jer se radništvo u međuvremenu udaljilo od obrazovanja i kulture te se odalo skitnji, alkoholu i hazardnim igrama. ${ }^{173}$ Krajem rujna 1923 . godine održana je konstituirajuća skupština, policija „Slobodi“ vraća zaplijenjenu imovinu dok neki

\footnotetext{
169 Isto, str. 15.

170 Isto, str. 16.

171 Prvi put nakon bune nezadovoljnih vojnika i radnika 1919. godine te ponovno nakon atentata na jugoslavenskog ministra Draškovića 1921. godine.

172 R.K.U.D. Sloboda u Varaždinu 1905.-1955., Varaždin, 1955., str. 63.

173 Josip Runjak, Sloboda - Vis 1905. - 1985., Nišro „Varaždin“, Varaždin, 1985., str. 46.
} 
članovi vraćaju i pohranjenu bankovnu knjižicu čime su se osigurala financijska sredstva za daljnji rad. Ipak, početni interes za radničko društvo bio je izrazito slab. ${ }^{174} \mathrm{U}$ periodu od 1925 . do 1929. godine bilježi se porast članstva, osobito mladih, a zahvaljujući dotaciji Radničke komore u Varaždinu dobiven je novac za nabavu novih instrumenata i općenito sredstva potrebna za rad. Društvo 1929. godine bilježi 140 članova što je bio popriličan broj za ondašnje prilike. Međutim, povremeno su rad društva ponovno opstruirale razmirice i neslaganja članova zbog političkog razilaženja u mišljenju. ${ }^{175}$

Novo teško razdoblje za „Slobodu“ nastupa uspostavom Diktature nakon čega je režim još intenzivnije progonio istaknute socijaldemokrate i onemogućavao rad radničkih udruga. Broj članova sa 140 pada na 104 već 1930. godine. $\mathrm{Ni}$ to nije omelo rad tamburaške, pjevačke i diletantske sekcije, organizaciju predavanja, zabava, plesnih škola i izleta u prirodu. „Sloboda“ do tada nije ni imala prave knjižnice. Društvo je samo posjedovalo nekoliko starih knjiga na njemačkome jeziku koje su besplatno stajale na raspolaganju članovima, no godinama nisu bile posuđene. ${ }^{176} \mathrm{Iz}$ tog se razloga javlja želja za osnivanjem društvene knjižnice s kvalitetnom literaturom kako bi se moglo započeti s intenzivnim ideološkim djelovanjem na radnike preko knjiga i rasprava o pročitanome. ${ }^{177}$ Kasnije je društvena knjižnica postala bitan faktor koji je radnike potaknuo na čitanje i debatiranje o pročitanim djelima s ciljem ideološkog izgrađivanja članstva. ${ }^{178}$

\footnotetext{
174 Isto, str. 46.

175 Isto, str. 46.

176 R.K.U.D. Sloboda u Varaždinu 1905.-1955., str. 69.

177 Isto, str. 69. - 70.

178 Za širenje marksističke ideologije među članovima društva važan je Slavko Lončarić koji je zbog ljevičarskoga političkoga opredjeljenja prognan iz Hrvatske Kostajnice u rodni Varaždin 1929. godine. Unatoč nadzoru policije uspijeva stupiti u kontakt sa „Slobodašima“ kojima daje knjige na čitanje. Nakon što bi pročitali knjige, članovi su se sastajali kako bi o njima raspravljali, a povremeno i zajedno iz njih čitali. Lončarić nije samo podučavao članove marksističkoj ideologiji, već je i u tajnosti nabavljao zagrebačke novine ljevičarskoga opredjeljenja za što je vladao veliki interes među članstvom. Čak se skupljao novac za stručnu literaturu te za pretplatu na Borbu, Organizovani radnik, Krležin i Cesarčev Plamen, Književnu republiku, a kasnije i za Zaštitu čovjeka.
} 


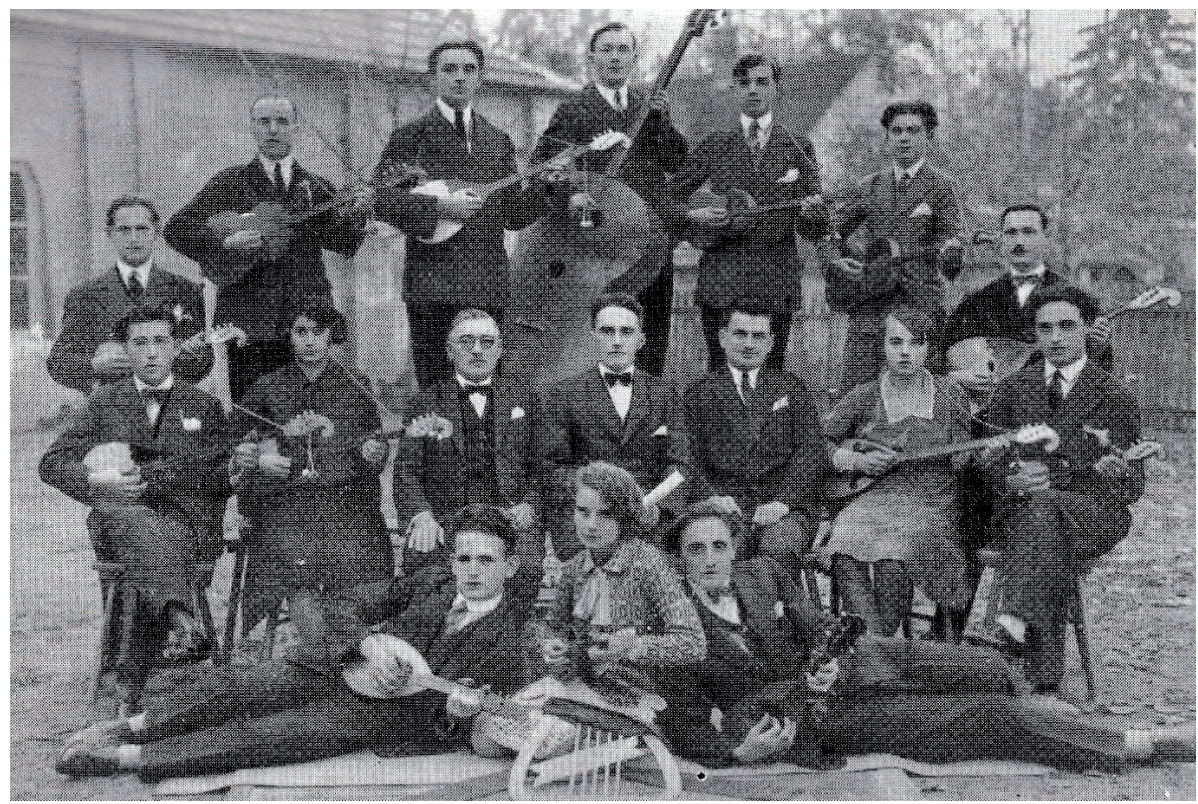

Slika 19. Fotografija članova "Slobodine“ tamburaške sekcije 1930. g. ${ }^{179}$

Kad 1931. godine arhivar i knjižničar postaje Franjo Starina, nabavljaju se nove knjige. Budući da društvo polako počinje napredovati, planira se obnova knjižnice i nabava prvenstveno proleterske literature. ${ }^{180}$ Dodatno se organizira tečaj za krojenje, predavanja i sastanci na temu nezaposlenosti koja je tada bila sve izraženija. ${ }^{181}$

Skupoća, tuberkuloza, izrabljivanje radnika i najniže radničke nadnice u državi obilježile su 1932. godinu kad, unatoč dotacijama Radničke komore i Gradskog načelstva, „Sloboda“ broji samo oko 30 članova pa redovna godišnja skupština 1932. godine konstatira nazadovanje društva. Stjepan Pongračić odabran je za predsjednika te ujedno saznajemo da funkciju arhivara (i knjižničara) nastavlja vršiti Starina. Novoizabrano rukovodstvo ulaže velike napore kako bi se povećao broj članova te ponovno steklo povjerenje i simpatije radnika. Jedna od metoda bila su zanimljiva predavanja liječnika o higijeni, zatim o potrebi radničke svijesti i klasnoga opredjeljenja. Društvo te godine nastavlja držati predispitne tečajeve za naučnike. Prvi pozitivni pomak uočen je kod dramske sekcije koja je 1932.

\footnotetext{
179 R.K.U.D. Sloboda u Varaždinu 1905.-1955., str. 77.

180 Josip Runjak, Sloboda - Vis 1905. - 1985., str. 53.-55.

${ }^{181}$ R.K.U.D. Sloboda u Varaždinu 1905.-1955., str. 77.
} 
godine priredila nekoliko uspješnih priredbi koje su dokazale da radništvo može ravnopravno s ostalim društvima sudjelovati u kulturnom životu grada. ${ }^{182}$

lako „Sloboda“ 1933. godine ima samo 40 članova, dolazi do prekretnice u radu te se priređuje niz predavanja, kulturnih priredbi s igrokazima dramske amaterske družine i recitacijama, zatim koncerti pjevačke i tamburaške sekcije, izleti te zabava za Fašnik. Te godine uz predavanja o alkoholu, značenju i radu radničke i namješteničke štampe, Karlu Marxu, značenju novca, transfuziji krvi i o zlatu, dr. Alfred Nick iz Zagreba održava predavanje o alkoholu te u sklopu tog predavanja prikazuje čak i film. ${ }^{183} \mathrm{Na}$ izvanrednoj sjednici 1. listopada 1933. godine Radničko naobrazbeno društvo "Sloboda" mijenja svoja pravila i ime koje sada glasi Radničko kulturno-prosvjetno društvo „Sloboda“. ${ }^{184}$ Ta je sjednica važna jer se na njoj ističe napredak čitaonice i knjižnice za koje postoji sve veći interes, a pročitano je 450 knjiga. ${ }^{185} \mathrm{Krajem}$ 1933. godine na poticaj dr. Eduarda Vrbanca oformljena je i „Esperantska sekcija“ koja je bila izuzetno popularna i uspješna - 20 radnika tečno je govorilo esperanto. Ponovno se organiziraju predavanja, igraju se nogometne utakmice, daju igrokazi, glazbene priredbe, organiziraju svečanosti i sl.

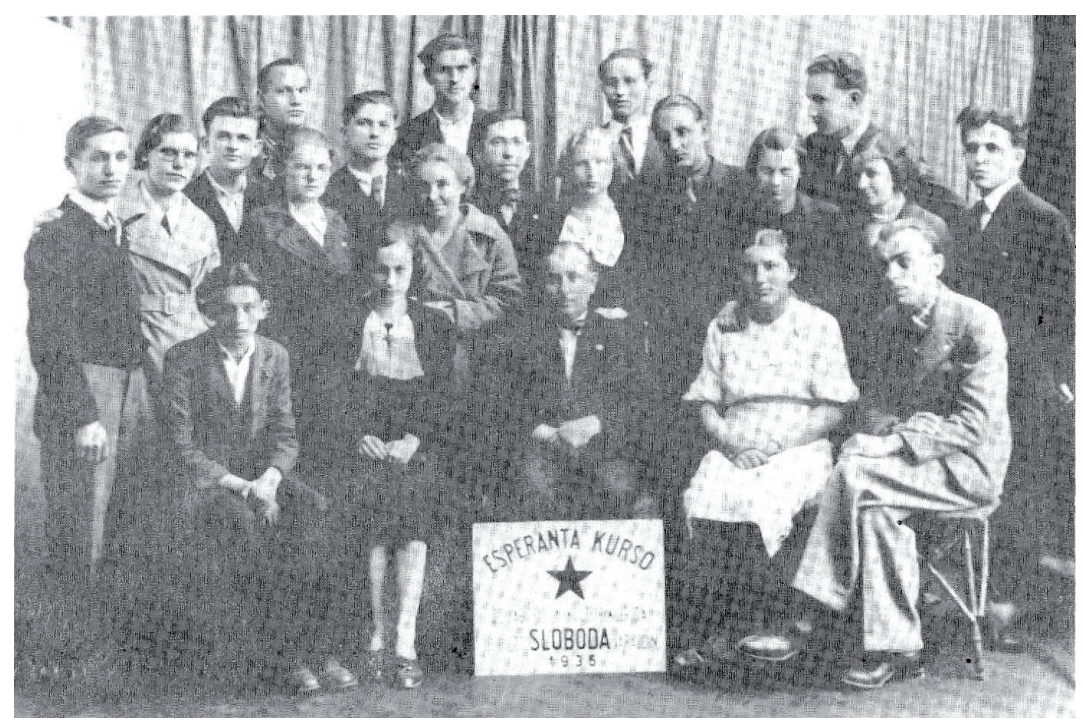

Slika 20. Fotografija članova radničke esperantske sekcije 1935. godine. ${ }^{186}$

\footnotetext{
182 Isto, str. 78.

183 Isto, str. 80.

184 Isto, str. 80. - 110.

185 Josip Runjak, Sloboda - Vis 1905. - 1985., str. 53.-55.

186 Josip Runjak, Sloboda - Vis 1905. - 1985., str. 80.
} 
lako se ekonomske prilike i dalje pogoršavaju, rad pjevačke sekcije uspješno je obnovljen 1934. godine te dolazi do dodatnog općeg napretka u cjelokupnom djelokrugu društva. Organiziraju se izleti u mjesta van Varaždina gdje se priređuju nastupi pjevačkog zbora i dramske sekcije. Predavanjima se nastavlja vršiti edukacija radnika i to na području socijalne politike, politike rada i kapitala, zatim na području radničkog osiguranja, socijalnog osiguranja, sindikalnih organizacija te esperanta. Te godine na skupštini društva knjižničar Tomo Korpar ističe da društvena knjižnica također napreduje te da je pročitano 560 knjiga dok knjižnicu koristi 60 od sveukupno 75 članova. ${ }^{187}$

Uoči proslave 30-godišnjice djelovanja društva povećava se broj članova na 85 , a cijelu 1935. godinu obilježava intenzivna aktivnost diletantske, pjevačke i esperantske sekcije. I te godine organizira se tečaj esperanta koji završava svečanom priredbom, kao i predavanja o npr. sifilisu, tuberkulozi, bakterijama i sl. Dramska sekcija uvježbava predstave te ih izvodi na kulturnim priredbama "Slobode“ na kojima nastupaju i pjevačka i tamburaška sekcija. Tako društvo 22. lipnja 1935. godine organizira koncerte u Varaždinu i Klenovniku zajedno s Radničkim pjevačkim društvom iz Zagreba. Te se godine „Sloboda“ uključuje i u prosvjetno-kulturni rad po okolnim selima organizacijom priredbi što ima posebno pozitivan utjecaj na mlade stanovnike sela, a buduće varaždinske radnike. Nažalost, taj oblik kulturno-prosvjetnoga rada po okolnim mjestima režim zabranjuje 1939. godine. ${ }^{188}$

Budući da knjižnica djeluje u sve značajnijem opsegu, od 1936. godine spominje se kao „Radnička knjižnica“, a tada funkciju knjižničara obavlja Antun Cvetković. ${ }^{189}$ Svoje aktivnosti te i sljedećih godina nastavljaju esperantski, tamburaški, pjevački, dramski i knjižničarski odvojci društva uz koje djeluje i sindikalna škola. Priređuju se koncerti, esperantske priredbe, izleti sa zabavama, kulturne večeri s nastupom pjevačkoga i tamburaškoga zbora, manji kazališni programi i recitacije. Društvo je često organiziralo koncerte s plesnim zabavama te izlete kako bi osiguralo novčana sredstva za nabavu novina i knjiga, ali i održavanje stručnih i edukacijskih tečajeva za radnike. ${ }^{190}$

Predsjednikom društva 1938. godine postaje Pero Bjelčić, no ne spominje se je li bilo izmjene knjižničara. Pjevački zbor nastupa čak i na festivalu radničkih pjevačkih društava u Mariboru te održava jedan zajednički koncert sa zagrebač-

\footnotetext{
187 Isto, str. 60.

188 R.K.U.D. Sloboda u Varaždinu 1905.-1955., str. 87.

189 Isto, str. 88.

190 Isto, str. 90.-91.
} 
kim Radničkim pjevačkim zborom „Jednakost“. Sloboda tada broji 100 članova za koje se u Radničkom domu svake srijede organiziraju redovna predavanja. Dalje djeluju pjevački zbor, esperantski tečaj, tamburaški zbor te knjižnica, no rad recitacijske skupine zabranjuje policija. ${ }^{191}$

Pred II. svjetski rat politički događaji u zemlji i svijetu nepovoljno su utjecali na rad društva, broj članova stagnira, no unatoč otežavajućim političkim okolnostima "Sloboda“ nastavlja s radom. ${ }^{192}$ Međutim, kako je rad društva onemogućavan na sve moguće načine, održano je svega nekoliko predavanja i to o problemu prosvjećivanja žena te o budućem radu Slobode. ${ }^{193}$

Početkom rata 1. rujna 1939. godine počinju teški dani za sve, a pogotovo za radništvo zbog učestalih otpuštanja te rasta nezaposlenosti. Intenzivno se radi na uništenju jedinstva radnika čiji se štrajkovi redovno guše, a ubrzo se zabranjuju i ukidaju sva društva i novine osim režimskih. Tako 1940. godine dolazi do zabrane rada "Slobode“ koja je općenito imala ključnu ulogu u obrazovanju, okupljanju i povezivanju naprednih radnika, njihovu odgoju, širenju naprednih svjetonazora te u podizanju klasne svijesti radnika i seljaštva. ${ }^{194}$

Na samom kraju pregleda rada najznačajnijih knjižnica u međuratnom razdoblju i opisu društva u sklopu kojih je većina njih djelovala bitno je naglasiti da je po završetku II. svjetskoga rata upravo Radničkom kulturno-umjetničkom društvu "Sloboda“ povjeren zadatak reorganizacije jedinstvene knjižnice nakon što je 1. prosinca 1947. godine spojena knjižna imovina Narodne čitaonice, Gradske pučke knjižnice i knjižnice Radničkog kulturno-umjetničkog društva "Sloboda“. Knjižnica i čitaonica osamostaljuju se i odvajaju od Radničkog kulturno-umjetničkoga društva Sloboda tek 1. siječnja 1949. godine te dalje djeluju pod nazivom Gradska knjižnica i čitaonica „Sloboda“. ${ }^{195}$

\section{ZAKLJUČAK}

Nakon završetka I. svjetskoga rata obnovom društvenoga i kulturnoga života dolazi i do obnove rada prijeratnih knjižnica koje su, kao dio privatnog vlasništva, samostana, škola, raznih društava te čitaonica bile zatvorenoga tipa. Najznačajnije varaždinske knjižnice zatvorenoga tipa u međuratnom razdoblju bile su one koje su djelovale u sklopu Narodne čitaonice, Jugoslavenskog akademskog

\footnotetext{
191 Isto, str. 102.

192 Josip Runjak, Sloboda - Vis 1905. - 1985., str. 77.

193 R.K.U.D. Sloboda u Varaždinu 1905.-1955., Varaždin, 1955., str. 103.

194 Isto, str. 105.

195 Drago Bišćan, „Gradska pučka knjižnica 1919.-1947.“, str. 47.
} 
društva „Tomislav“ i Radničkog prosvjetno-kulturnog društva „Sloboda“. Kako je u cijeloj državi postojala potreba za utemeljenjem javnih, pučkih knjižnica s ciljem prosvjetnog i kulturnog djelovanja na šire slojeve društva i pučanstva, već početkom 1919. godine osnovana je varaždinska Gradska pučka knjižnica. Tako knjige, novine i časopisi postaju dostupni i širim društvenim slojevima zahvaljujući upravo inicijativi Gradskoga poglavarstva, Narodne čitaonice i Jugoslavenskog akademskog društva „Tomislav“ koji su udruženim snagama, donacijama knjiga, novčanom potporom i savjetodavnim aktivnostima bili potpora Gradskoj pučkoj knjižnici koja je nakon samo nekoliko godina svojim inventarom premašila sve ostale knjižnice u gradu. Nakon gašenja Jugoslavenskog akademskog društva „Tomislav“ koje je najagilnije radilo na pučko-prosvjetnim aktivnostima u varaždinskoj okolici, sav novac dobiven od likvidacije tog društva kao i preostali knjižni inventar poklonjeni su upravo Gradskoj pučkoj knjižnici. Varaždinske su knjižnice, dakle, odigrale ključnu ulogu u prosvjećivanju Varaždinaca u međuratnom razdoblju. Štoviše, društva u sklopu kojih su djelovale najznačajnije knjižnice u razdoblju između dvaju svjetskih ratova bila su inicijatori različitih društvenih zbivanja i organizatori kulturnih manifestacija poput glazbenih koncerata, matineja, kazališnih priredbi, predavanja, tečajeva stranih jezika i esperanta, večernje škole, plesova, sportskih susreta, izleta, dobrotvornih akcija i sl. Dokaz je superiornog kulturnog i prosvjetnog značaja varaždinskih društava u sklopu kojih se odvijala knjižnična djelatnost činjenica da je neko vrijeme nakon završetka II. svjetskog rata upravo Radničkom prosvjetno-kulturnom društvu „Sloboda“ povjeren zadatak ujedinjenja knjižne imovine međuratne Gradske pučke knjižnice, Narodne čitaonice i Radničkog kulturno-umjetničkog društva "Sloboda“, čime je nastala nova knjižnična institucija imena Knjižnica i čitaonica "Sloboda“.

\section{LITERATURA}

1/ Drago BIŠĆAN, »Gradska pučka knjižnica 1919.-1947.«, Godišnjak Gradske knjižnice i čitaonice »Metel Ožegović« Varaždin, Broj 1, gl. ur. Marijan Kraš, Uvetisk d.o.o., Varaždin, 1995.

2/ Siniša HORVAT, "Historijat Varaždinske gimnazijske ekstenze», Hrvatska akademija znanosti i umjetnosti, Radovi Zavoda za znanstveni rad Varaždin, 14$15 / 2004$.

3/ Rudolf MAIXNER, "Akademsko društvo Tomislav u Varaždinu«, Zbornik za pučku prosvjetu, Svezak 1-2, Pučko sveučilište u Zagrebu, Zagreb, 1992.

4/ Pravilnik društvene knjižnice Jugoslavenskog akademskog društva »Tomislav«, Varaždin, 1918. 
5/ Pravilnik za putujuće knjižnice Jugoslavenskog akademskog društva »Tomislav«, Varaždin, 1919.

6/ Spomenspis Radničkog kulturno-prosvjetnog društva "Sloboda" 1905.1935., glavni i odgovorni urednik Pongračić Stjepan, Tisak "Svobodine narodne tiskare«, Varaždin, 1935.

7/ R.K.U.D. Sloboda u Varaždinu 1905.-1955., Varaždin, 1955.

8/ Josip RUNJAK, Sloboda - Vis 1905. - 1985., Nišro »Varaždin«, Varaždin, 1985.

\section{OSTALI IZVORI PODATAKA}

1/ Arhivska građa Gradske knjižnice i čitaonice »Metel Ožegović« Varaždin

2/ Novinstvo Varaždina, http://library.foi.hr/nv/

\section{SAŽETAK}

\section{KNJIŽNIČNA DJELATNOST U VARAŽDINU IZMEĐU DVAJU SVJETSKIH RATOVA}

U Varaždinu je između dvaju svjetskih ratova postojala intenzivna knjižnična djelatnost. Većina značajnijih knjižnica bila je zatvorenog tipa, a djelovale su u sklopu različitih varaždinskih društava. Društva Narodna čitaonica, Jugoslavensko akademsko društvo "Tomislav" i Radničko prosvjetno-kulturno društvo „Sloboda“ u međuratnom razdoblju imali su knjižnice te su putem knjiga, novina, časopisa, predavanja i ostalih aktivnosti marljivo radili na širenju kulture i prosvjećivanju Varaždinaca. Kako bi knjige, novine te časopisi postali dostupni i širim društvenim slojevima, početkom 1919. godine osnovana je Gradska pučka knjižnica zahvaljujući inicijativi Gradskoga poglavarstva, Narodne čitaonice i Jugoslavenskog akademskog društva „Tomislav“. Štoviše, neko vrijeme nakon završetka II. svjetskog rata upravo je ujedinjenjem knjižne imovine međuratne Gradske pučke knjižnice, Narodne čitaonice i Radničkog kulturno-umjetničkog društva "Sloboda" nastala nova institucija imena Knjižnica i čitaonica "Sloboda".

Ključne riječi: Varaždin; međuratno razdoblje; knjižnica; čitaonica; kultura; prosvjećivanje. 


\section{SUMMARY}

\section{LIBRARIES IN VARAŽDIN BETWEEN THE TWO WORLD WARS}

In Varaždin, the period between the two world wars was marked by intense activities involving libraries. The majority of significant libraries were closed stack libraries functioning within various Varaždin societies. During the interwar period the National Reading Room, Yugoslav Academic Society "Tomislav" and Workers' Educational and Cultural Society "Sloboda" had their own libraries, and through books, newspapers, magazines, lectures and other activities they worked diligently on broadening the culture and education in Varaždin. In order to make books, newspapers and magazines accessible to all society layers the Public Town Library was founded at the beginning of the $19^{\text {th }}$ century due to the initiative of the Town Government, National Reading Room and Yugoslav Academic Society "Tomislav". Moreover, some time after the end of the Second World War library items belonging to the Public Town Library, National Reading Room and Workers' Educational and Cultural Society "Sloboda" functioning in the interwar period, were merged for the purpose of founding a new institution named Library and Reading Room "Sloboda".

Key Words: Varaždin; interwar period; libraries; reading rooms; culture; enlightenment. 
